\title{
Characterization and high-efficiency secreted expression in Bacillus subtilis of a thermo-alkaline $\beta$-mannanase from an alkaliphilic Bacillus clausii strain S10
}

\author{
Cheng Zhou ${ }^{1 *}$, Yanfen Xue $\mathrm{e}^{1,2}$ and Yanhe Ma $\mathrm{M}^{1,2^{*}}$
}

\begin{abstract}
Background: $\beta$-Mannanase catalyzes the cleavage of $\beta-1,4-$ linked internal linkages of mannan backbone randomly to produce new chain ends. Alkaline and thermostable $\beta$-mannanases provide obvious advantages for many applications in biobleaching of pulp and paper, detergent industry, oil grilling operation and enzymatic production of mannooligosaccharides. However, only a few of them are commercially exploited as wild or recombinant enzymes, and none heterologous and secretory expression of alkaline $\beta$-mannanase in Bacillus subtilis expression system was reported. Alkaliphilic Bacillus clausii S10 showed high $\beta$-mannanase activity at alkaline condition. In this study, this $\beta$-mannanase was cloned, purified and characterized. The high-level secretory expression in B. subtilis was also studied.
\end{abstract}

Results: A thermo-alkaline $\beta$-mannanase (BcManA) gene encoding a 317-amino acid protein from alkaliphilic Bacillus clausii strain was cloned and expressed in Escherichia coli. The purified mature BcManA exhibited maximum activity at $\mathrm{pH} 9.5$ and $75^{\circ} \mathrm{C}$ with good stability at $\mathrm{pH} 7.0-11.5$ and below $80^{\circ} \mathrm{C}$. BcManA demonstrated high cleavage capability on polysaccharides containing $\beta$-1,4-mannosidic linkages, such as konjac glucomannan, locust bean gum, guar gum and sesbania gum. The highest specific activity of $2366.2 \mathrm{U} \mathrm{mg}^{-1}$ was observed on konjac glucomannan with the $K_{m}$ and $k_{\text {cat }}$ value of $0.62 \mathrm{~g} \mathrm{l}^{-1}$ and $1238.9 \mathrm{~s}^{-1}$, respectively. The hydrolysis products were mainly oligosaccharides with a higher degree of polymerization than biose. BcManA also cleaved manno-oligosaccharides with polymerization degree more than 3 without transglycosylation. Furthermore, six signal peptides and two strong promoters were used for efficiently secreted expression optimization in B. subtilis WB600 and the highest extracellular activity of $2374 \mathrm{U} \mathrm{ml}^{-1}$ with secretory rate of $98.5 \%$ was obtained using $\mathrm{SP}_{\text {lipA }}$ and P43 after $72 \mathrm{~h}$ cultivation in $2 \times \mathrm{SR}$ medium. By medium optimization using cheap nitrogen and carbon source of peanut meal and glucose, the extracellular activity reached $6041 \mathrm{U} \mathrm{ml}^{-1}$ after $72 \mathrm{~h}$ cultivation with $6 \%$ inoculum size by shake flask fermentation.

Conclusions: The thermo-alkaline $\beta$-mannanase BcManA showed good thermal and pH stability and high catalytic efficiency towards konjac glucomannan and locust bean gum, which distinguished from other reported $\beta$-mannanases and was a promising thermo-alkaline $\beta$-mannanase for potential industrial application. The extracellular BcManA yield of $6041 \mathrm{U} \mathrm{ml}^{-1}$, which was to date the highest reported yield by flask shake, was obtained in $B$. subtilis with constitutive expression vector. This is the first report for secretory expression of alkaline $\beta$-mannanase in B. subtilis protein expression system, which would significantly cut down the production cost of this enzyme. Also this research would be helpful for secretory expression of other $\beta$-mannanases in B. subtilis.

Keywords: Thermo-alkaline $\beta$-mannanase, Bacillus clausii, Characterization, Secreted expression, Bacillus subtilis

\footnotetext{
*Correspondence: zhoucheng@im.ac.cn; mayanhe@im.ac.cn

1 State Key Laboratory of Microbial Resources, Institute of Microbiology,

Chinese Academy of Sciences, Beijing 100101, China

Full list of author information is available at the end of the article
} 


\section{Background}

$\beta$-Mannanase, as one of the mannan-degrading enzymes, plays an important role in the hydrolysis of hemicellulose and catalyzes the cleavage of $\beta$-1,4-linked internal linkages of mannan backbone randomly to produce new chain ends $[1,2]$. $\beta$-mannanases have many potential applications in industrial processes such as biobleaching of pulp and paper, detergent industry, food and feed industry, coffee processing industry, oil and gas industry, pharmaceutical applications, and second generation biofuel [1]. They are also involved in breaking down plant tissues in the cell walls [3] as well as digesting and absorbing nutrients in lower animals by degrading mannan polymers [4]. Owing to the importance and increasing application demand, many $\beta$-mannanases from different biological sources have been studied by purification, gene cloning, enzymatic characterization, structure and catalytic mechanisms, and engineering of improved features $[1,5]$. Besides a few $\beta$-mannanases from plants to lower animals $[3,4]$, most of reported $\beta$-mannanases were from microorganisms including fungi and bacteria. Among bacteria, $\beta$-mannanases were mostly produced by Gram-positive strains like Bacillus species [6-14] and Clostridia species [15]. Only a few Gram negative strains such as Pseudomonas [16], Vibrio [17], Thermotoga [18], Rhodothermus [19], Klebsiella [20] and Enterococcus [21] have been reported to produce $\beta$-mannanase. Besides these, some $\beta$-mannanases from actinomycetes such as Streptomyces [22], Cellulomonas [23] and Thermobifida [24] have also been studied. For fungi, the most common mannolytic group belongs to the genus Aspergillus [25-29], while some species from genus Penicillium [30], Trichoderma [31] and Neosartorya [32] have also been investigated. Particularly, $\beta$-mannanases from extremophilic microorganisms have drawn special attention due to their unusual properties like thermo-, acid-, or alkalitolerance which may be desirable for specific industrial processes [33]. Thermo-alkaline $\beta$-mannanases were usually used in biobleaching of pulp and paper, detergent industry, oil grilling operation and enzymatic production of mannooligosaccharides because of their high activity and good stability at high $\mathrm{pH}$ value and temperature [1]. Although a number of alkaline and thermostable mannanases were reported in the past decades, only a few are commercially exploited as wild or recombinant enzymes [34-36]. Therefore, there is still a pressing need to seek for new enzymes that are efficient and stable at alkaline or high temperature conditions to promote the development of the industrial application of $\beta$-mannanases.

In addition to enzyme properties, high yield is another important factor in the industrial application of enzymes. However, the yield of $\beta$-mannanases produced from native microbes, especially from extremophilic microbes, is usually low and hard to be improved, which led to the increasing attention on the heterologous production of $\beta$-mannanases in recent years [33]. Many $\beta$-mannanase genes originated from different microbes have been cloned and heterologously expressed in the frequently used protein expression systems such as Escherichia coli [37-39], Pichia pastoris [33, 40-42] and Bacillus subtilis [5, 43, 44] in the past decade. Compared to E. coli, P. pastoris and B. subtilis can secreted the enzyme directly into the culture medium, which making the downstream separation and purification much easier. However, most of the reported $\beta$-mannanases expressed in these two expression systems were acidic or neutral enzymes and only alkaline $\beta$-mannanase gene from alkaliphilic Bacillus sp. N16-5 was found heterologously expressed in P. pastoris with the highest yield of $1114 \mathrm{U} \mathrm{ml}^{-1}$ and $6336 \mathrm{U} \mathrm{ml}^{-1}$ by shake flask and fed-batch fermentation, respectively $[33,45]$. No heterologous and secreted expression of alkaline $\beta$-mannanase in $B$. subtilis was reported in the literature. In addition, $B$. subtilis possesses its own advantages in generally producing proteins with higher secretion concentration and well-characterized secretion pathways compared to P. pastoris [5]. Even when comparable secretion capacity occurs, B. subtilis still shows higher growth rate than $P$. pastoris, which makes it a priority in industrial application. On the other hand, bacteria producing $\beta$-mannanase, especially alkaline $\beta$-mannanases, are mostly confined to Gram-positives including various Bacillus species. Therefore, $B$. subtilis would be preferred expression system for highlevel secreted production of $\beta$-mannanases including alkaline $\beta$-mannanases originated from Bacillus strains.

In previous research, we isolated an alkaliphilic strain identified as Bacillus clausii strain S10 from soda lake in Inner Mongolia, China, which showed high alkaline $\beta$-mannanase activity. In this study, we described the gene cloning, heterologous expression, purification and characterization of this alkaline $\beta$-mannanase BcManA. Further a recombinant $B$. subtilis WB600 strain containing pMA5 vector carrying the BcManA gene was constructed. Different signal peptides and strong promoters were also used for the evaluation of high-level secreted production, along with the medium and inoculum amount optimization. Finally, the highest yield of $\beta$-mannanase reported to date by shake flask was obtained.

\section{Methods}

Strains, plasmids, and materials

Alkaliphilic strain B. clausii S10 which was used to clone the mannanase gene was isolated from a soda lake in Inner Mongolia of China. B. clausii S10 was 
preserved in the China General Microbiological Culture Collection Center (CGMCC 1.15293). The plasmids and bacteria strains used in this study for gene cloning and expression are listed in Table 1. Mannooligosaccharides (mannobiose, mannotriose, mannotetraose, mannopentose, and mannohexose) were purchased from Megazyme (Wicklow, Ireland). All the enzymes for DNA manipulations were purchased from NEB Inc. (Ipswich, MA, USA). Isopropyl- $\beta$-Dthiogalactopyranoside (IPTG), ampicillin, kanamycin and imidazole were from Amresco Inc. (Solon, OH, USA). All other chemicals were of reagent grade.

\section{Gene cloning of BcManA}

The genomic DNA of B. clausii S10 was extracted using Bacterial DNA Kit (OMEGA Bio-tek, Norcross, USA), and the restriction enzyme Sau3A was employed to obtain randomly digested chromosomal fragments. The 4.0- to $8.0-\mathrm{kb}$ fragments were recovered and purified by a Gel Extraction Kit (OMEGA Bio-tek) and ligated into
pUC118 vector previously digested with BamHI and treated with calf intestinal alkaline phosphatase. The ligation product was then transformed into E. coli $\mathrm{DH} 5 \alpha$ cells by electroporation transformation and plated onto Luria-Bertani (LB) agar plates containing $60.0 \mu \mathrm{g} \mathrm{ml}$ of ampicillin and incubated at $37{ }^{\circ} \mathrm{C}$ overnight. Grown colonies were picked with sterilized toothpicks, plated in $150.0 \mu \mathrm{l} \mathrm{LB}$ medium containing ampicillin $\left(60.0 \mu \mathrm{g} \mathrm{ml}^{-1}\right)$ in sterilized 96-well microplates, and incubated overnight at $37{ }^{\circ} \mathrm{C}$ with shaking at $900 \mathrm{rpm}$. Fifty microliters of sterilized $60.0 \%$ glycerol was then added to each well, and plates were stored at $-80{ }^{\circ} \mathrm{C}$ to create the genomic DNA library.

Colonies in the microplate were spotted onto LBampicillin $\left(60.0 \mu \mathrm{g} \mathrm{ml}^{-1}\right)$ agar medium ( $\left.\mathrm{pH} 8.0\right)$ containing $0.5 \%$ locust bean gum by a sterile 96 -pin replicator. After cultivating for $20 \mathrm{~h}$ at $37{ }^{\circ} \mathrm{C}, 1.0 \%$ sterile Congo red solution was softly poured onto the LB agar medium over the colonies. The colony which has transparent zone after 15 min soakage was considered to be the positive

Table 1 Plasmids and strains used in this study

\begin{tabular}{|c|c|c|}
\hline Plasmids or strains & Features & Sources \\
\hline pUC118 & Treated by BamHI and calf intestinal alkaline phosphatase, $\mathrm{Amp}^{R}$ & TaKaRa Co., Ltd, China \\
\hline pET28a & Protein expression vector in E. coli, $\mathrm{Kan}^{\mathrm{R}}$ & Merck Co., Germany \\
\hline pET28a-Man & pET28a derivative with BcManA gene without signal peptide & This work \\
\hline pUC57-Simple-Plaps & pUC57 derivative with promoter $\mathrm{P}_{\text {laps }}$ sequence & Laboratory preservation \\
\hline pHT43 & E. coli-Bacillus shuttle vector for protein expression in B. subtilis, $\mathrm{Cm}^{\mathrm{R}}$ & BGSC, USA \\
\hline pMA5 & E. coli-Bacillus shuttle vector for protein expression in B. subtilis, $\operatorname{Kan}^{\mathrm{R}}$ & BGSC, USA \\
\hline pMA5-Man & pMA5 derivative with BcManA gene without signal peptide & This work \\
\hline pMA5-Man1 & pMA5-Man derivative, original signal peptide, $\mathrm{SP}_{\text {ori }}$ & This work \\
\hline pMA5-Man2 & pMA5-Man derivative, $\mathrm{SP}_{\text {lipA }}$ & This work \\
\hline pMA5-Man3 & pMA5-Man derivative, $\mathrm{SP}_{\text {amyE }}$ & This work \\
\hline pMA5-Man4 & pMA5-Man derivative, $\mathrm{SP}_{\text {lipB }}$ & This work \\
\hline pMA5-Man5 & PMA5-Man derivative, $\mathrm{SP}_{\text {aprE }}$ & This work \\
\hline pMA5-Man6 & pMA5-Man derivative, $\mathrm{SP}_{\text {amyL }}$ & This work \\
\hline pMA5-Man2-1 & pMA5-Man2 derivative, P43 & This work \\
\hline pMA5-Man2-2 & pMA5-Man2 derivative, $\mathrm{P}_{\text {laps }}$ & This work \\
\hline B. clausii $\mathrm{S} 10$ & DNA source for $\beta$-mannanase gene cloning & Laboratory preservation \\
\hline E. coli DH5a & Host for gene cloning & Transgen Biotech Co., Ltd, China \\
\hline E. coli BL21(DE3) & Host for protein expression & Transgen Biotech Co., Ltd, China \\
\hline B. subtilis WB600 & Host for protein secreted expression, $\mathrm{Cm}^{\mathrm{R}}$ & Laboratory preservation \\
\hline B. subtilis WB600-1 & WB600 derivative, pMA5-Man, $\mathrm{Kan}^{\mathrm{R}}, \mathrm{Cm}^{\mathrm{R}}$ & This work \\
\hline B. subtilis WB600-2 & WB600 derivative, pMA5-Man1, $\mathrm{Kan}^{\mathrm{R}}, \mathrm{Cm}^{\mathrm{R}}$ & This work \\
\hline B. subtilis WB600-3 & WB600 derivative, pMA5-Man2, $\mathrm{Kan}^{\mathrm{R}}, \mathrm{Cm}^{\mathrm{R}}$ & This work \\
\hline B. subtilis WB600-4 & WB600 derivative, pMA5-Man3, $\mathrm{Kan}^{\mathrm{R}}, \mathrm{Cm}^{\mathrm{R}}$ & This work \\
\hline B. subtilis WB600-5 & WB600 derivative, pMA5-Man4, $\mathrm{Kan}^{\mathrm{R}}, \mathrm{Cm}^{\mathrm{R}}$ & This work \\
\hline B. subtilis WB600-6 & WB600 derivative, pMA5-Man5, $\mathrm{Kan}^{\mathrm{R}}, \mathrm{Cm}^{\mathrm{R}}$ & This work \\
\hline B. subtilis WB600-7 & WB600 derivative, pMA5-Man6, $\mathrm{Kan}^{\mathrm{R}}, \mathrm{Cm}^{\mathrm{R}}$ & This work \\
\hline B. subtilis WB600-8 & WB600 derivative, pMA5-Man2-1, $\mathrm{Kan}^{\mathrm{R}}, \mathrm{Cm}^{\mathrm{R}}$ & This work \\
\hline B. subtilis WB600-9 & WB600 derivative, pMA5-Man2-2, $\operatorname{Kan}^{R}, \mathrm{Cm}^{R}$ & This work \\
\hline
\end{tabular}


colony with mannanase activity. The inserted fragment in the positive transformant was sequenced by SinoGenoMax Co., Ltd. (Beijing, China). The gene sequence was analyzed by the NCBI BLAST program, and the SignalP 4.1 server (http://www.cbs.dtu.dk/services/SignalP/) was used for signal peptide prediction. The amino acid sequence was aligned with ClustalX.

\section{Expression and purification of the recombinant mature BcManA in E. coli}

The mature BcManA-encoding gene without a signal peptide sequence was obtained by PCR using the primer pair of $\mathrm{F}$ (5'-CTAGCTAGCCAAAGCGGCTTTCAC GTAAAAG- $3^{\prime}$, where the underline indicates the NheI site) and $\mathrm{R}$ (5'-CCCAAGCTTTTAATCACGTTTGAG CCCATTTTC-3', where the underline indicates the HindIII site). The following PCR program was used: 1 cycle of $94{ }^{\circ} \mathrm{C}$ for $3 \mathrm{~min} ; 30$ cycles of $94{ }^{\circ} \mathrm{C}$ for $30 \mathrm{~s}, 56^{\circ} \mathrm{C}$ for $35 \mathrm{~s}$, and $72{ }^{\circ} \mathrm{C}$ for $1 \mathrm{~min}$; followed by a final extension at $72{ }^{\circ} \mathrm{C}$ for $10 \mathrm{~min}$. The PCR product was purified using a Gel Extraction Kit (OMEGA Bio-tek) and then digested with NheI and HindIII for ligation to the pET28a which were cleaved with the same enzymes. The resultant recombinant plasmid pET28a-manA was transformed into E. coli BL21 (DE3) for gene expression. For gene expression in flask, about $2.0 \mathrm{ml}$ of seed culture of recombinant $E$. coli BL21 (DE3) harboring pET28a-manA was inoculated into $150.0 \mathrm{ml}$ of LB medium containing $60.0 \mu \mathrm{g} \mathrm{ml}^{-1}$ of kanamycin for cultivation. IPTG with a final concentration of $0.8 \mathrm{mM}$ was added when the $\mathrm{OD}_{600}$ reached 0.6. And then the protein expression was induced by addition of IPTG at $37^{\circ} \mathrm{C}$ for $5 \mathrm{~h}$ with shaking at $200 \mathrm{rpm}$.

The mature BcManA encoding gene was expressed as a recombinant fusion protein containing an $\mathrm{N}$-terminal His-tag in E. coli and was purified to near homogeneity by a two-step process including heat treatment and nickelnitrilotriacetic acid (Ni-NTA) affinity chromatography. Cells of about $150.0 \mathrm{ml}$ culture of $E$. coli BL21 (DE3) harboring pET28a-ManA were harvested by centrifugation at $8000 \times g$ at $4{ }^{\circ} \mathrm{C}$ for $15 \mathrm{~min}$, washed with binding buffer (20 mM Tris- $\mathrm{HCl}$ buffer containing $500 \mathrm{mM} \mathrm{NaCl}$ and $5 \mathrm{mM}$ imidazole, $\mathrm{pH} 7.9$ ) and then suspended in $20.0 \mathrm{ml}$ of the same buffer. The suspended cells were disrupted by sonication and the supernatant was obtained by centrifugation at $16,000 \times g$ for $10 \mathrm{~min}$ at $4{ }^{\circ} \mathrm{C}$. The supernatant was incubated at $60{ }^{\circ} \mathrm{C}$ for $20 \mathrm{~min}$ and then centrifuged at $16,000 \times g$ for $15 \mathrm{~min}$ at $4{ }^{\circ} \mathrm{C}$. The second supernatant was loaded onto a pre-equilibrated Ni-NTA column filled with Ni-NTA His.Bind Resin (Novagen, CA, USA) followed by washing with $10.0 \mathrm{ml}$ of binding buffer and subsequently with $15.0 \mathrm{ml}$ of washing buffer $(20 \mathrm{mM}$ Tris- $\mathrm{HCl}$ buffer containing $500 \mathrm{mM} \mathrm{NaCl}$ and $60 \mathrm{mM}$ imidazole, $\mathrm{pH}$ 7.9). Finally, the protein was eluted with $3.0 \mathrm{ml}$ of elution buffer (20 mM Tris- $\mathrm{HCl}$ buffer containing $500 \mathrm{mM} \mathrm{NaCl}$ and $1 \mathrm{M}$ imidazole, $\mathrm{pH}$ 7.9).

The obtained protein solution was desalted using a desalting column (GE Healthcare Bio-Sciences AB, Uppsala, Sweden) with $20 \mathrm{mM}$ Tris- $\mathrm{HCl}$ buffer ( $\mathrm{pH}$ 7.5). The purity of the proteins was assessed by sodium dodecyl sulfate polyacrylamide gel electrophoresis (SDS-PAGE). The protein concentration was determined by Quick Start Bradford protein assay (Bio-Rad, Hercules, CA, USA) with bovine serum albumin $\left(0.125-1.0 \mathrm{mg} \mathrm{ml}^{-1}\right)$ as standard.

\section{Activity assay of BcManA}

The enzymatic activity of BcManA was determined by measuring the release of reducing sugars by the 3,5-dinitrosalicylic acid (DNS) method with mannose as the standard. The reaction mixture comprised $190.0 \mu \mathrm{l}$ of $50 \mathrm{mM}$ glycine- $\mathrm{NaOH}(\mathrm{pH}$ 9.5) containing $0.5 \%$ substrate $(\mathrm{w} / \mathrm{v})$, and $10.0 \mu \mathrm{l}$ of appropriately diluted enzyme solution. The reaction was incubated at $70{ }^{\circ} \mathrm{C}$ for $10 \mathrm{~min}$ and stopped by adding $200.0 \mu \mathrm{l}$ DNS reagent, followed by heating in a boiling water bath for $5 \mathrm{~min}$. The absorbance at $540 \mathrm{~nm}$ was measured with a Spectra Max 190 Microplate Reader (Molecular Devices, Sunnyvale, CA, USA). One unit of enzyme activity is defined as the amount of enzyme required to release $1 \mu \mathrm{mol}$ of mannose-reducing sugar equivalents per min. The activity measurements were repeated three times.

\section{Effect of $\mathrm{pH}$, temperature and reagents on enzyme activity and stability}

The optimal $\mathrm{pH}$ was assayed at $70{ }^{\circ} \mathrm{C}$ in $50 \mathrm{mM}$ $\mathrm{Na}_{2} \mathrm{HPO}_{4}$-Citric acid buffer ( $\mathrm{pH}$ 5.5-7.5), $50 \mathrm{mM}$ Tris$\mathrm{HCl}$ buffer (pH 7.5-8.5), $50 \mathrm{mM}$ glycine- $\mathrm{NaOH}$ buffer (pH 8.5-10.5) and $25 \mathrm{mM} \mathrm{Na}_{2} \mathrm{CO}_{3}-\mathrm{NaOH}$ buffer $(\mathrm{pH}$ $10.5-11.5)$ containing $0.5 \%$ konjac glucomannan $(\mathrm{w} / \mathrm{v})$. The optimal temperature was assayed at $40-90{ }^{\circ} \mathrm{C}$ for $10 \mathrm{~min}$ with standard reaction buffer $(50 \mathrm{mM}$ glycine$\mathrm{NaOH}$ buffer containing $0.5 \%$ konjac glucomannan $(\mathrm{w} / \mathrm{v})$, $\mathrm{pH}$ 9.5). The effect of $\mathrm{pH}$ on enzyme stability was analyzed with enzyme being incubated in $\mathrm{Na}_{2} \mathrm{HPO}_{4}$-Citric acid buffer ( $\mathrm{pH} 4.5-7.5), 50 \mathrm{mM}$ Tris- $\mathrm{HCl}$ buffer $(\mathrm{pH}$ 7.5-8.5), $50 \mathrm{mM}$ glycine- $\mathrm{NaOH}$ buffer $(\mathrm{pH} 8.5-10.5)$ and $\mathrm{Na}_{2} \mathrm{HPO}_{4}-\mathrm{NaOH}$ buffer (pH $\left.11.0-12.0\right)$ at $30{ }^{\circ} \mathrm{C}$ for $6 \mathrm{~h}$. Thermal stability was determined by measuring the residual activity after incubating enzyme in $50 \mathrm{mM}$ glycine- $\mathrm{NaOH}$ buffer ( $\mathrm{pH}$ 9.0) for different time at temperature of $50{ }^{\circ} \mathrm{C}, 60{ }^{\circ} \mathrm{C}, 70{ }^{\circ} \mathrm{C}$ and $80{ }^{\circ} \mathrm{C}$, respectively. For determining the thermostability at $70{ }^{\circ} \mathrm{C}$ and $80{ }^{\circ} \mathrm{C}$, the residual activity was assayed after incubation for $0.5,1.0$, 1.5, 2.0, 2.5, 3.0 and $4.0 \mathrm{~h}$. For assessing thermostability 
at $50{ }^{\circ} \mathrm{C}$ and $60{ }^{\circ} \mathrm{C}$, the incubation time was extended to $9.0 \mathrm{~h}$. All the measurements were repeated three times.

Influence of metal ions and some reagents on enzyme activity was determined by incubating the enzyme in $1 \mathrm{mM}$ of metal ions $\left(\mathrm{Hg}^{2+}, \mathrm{Mg}^{2+}, \mathrm{Na}^{+}, \mathrm{Mn}^{2+}, \mathrm{Zn}^{2+}\right.$, $\mathrm{Cu}^{2+}, \mathrm{Pb}^{2+}, \mathrm{Ca}^{2+}, \mathrm{Ag}^{+}, \mathrm{Fe}^{3+}, \mathrm{K}^{+}, \mathrm{Rb}^{+}, \mathrm{Cs}^{+}, \mathrm{Fe}^{2+}, \mathrm{Ni}^{2+}$ and $\mathrm{Co}^{2+}$ ) and EDTA by measuring the relative activity under the standard assay condition. The effect of some protein denatures such as SDS, on enzyme stability was determined by the residual activity after incubation them of different concentration with the enzyme of $0.1 \mathrm{mg} \mathrm{ml}^{-1}$ at $30{ }^{\circ} \mathrm{C}$ for $30 \mathrm{~min}$.

\section{Substrate specificity and kinetic parameters}

The substrate specificity of purified recombinant BcManA was assayed by incubating the enzyme solution with $0.5 \%(\mathrm{w} / \mathrm{v})$ substrates, including konjac glucomannan, locust bean gum, guar gum, sesbania gum, carboxymethyl cellulose, xylan, glucan, pectin, chitin, soluble starch and $\alpha$-1,6-linked yeast mannan under standard reaction conditions ( $\mathrm{pH} 9.5$ and $75^{\circ} \mathrm{C}$ ). To detect the exoglycosidase activity, the $p$-nitrophenyl glycoside substrate ( $5 \mathrm{mM}$ ) was incubated with $1 \mu \mathrm{M}$ enzyme for $30 \mathrm{~min}$. The release of $p$-nitrophenol was monitored by measuring the absorbance at $405 \mathrm{~nm}$. The hydrolysis kinetic parameters were determined at $75^{\circ} \mathrm{C}$ in $50 \mathrm{mM}$ glycine- $\mathrm{NaOH}$ buffer ( $\mathrm{pH}$ 9.5) after a reaction time of $10 \mathrm{~min}$ using $0.1 \mu \mathrm{M}$ enzyme and substrate of konjac glucomannan (0.3-5.0 mg ml $\left.\mathrm{mg}^{-1}\right)$, locust bean gum $\left(0.5-6.0 \mathrm{mg} \mathrm{ml}^{-1}\right)$, guar gum (1.0-8.0 mg ml $\mathrm{m}^{-1}$ ) and sesbania gum (1.0$8.0 \mathrm{mg} \mathrm{ml}^{-1}$ ). The $k_{c a t}$ and $K_{m}$ values were calculated by GraphPad Prism 5.0 software (http://www.graphpad. $\mathrm{com} /$ prism/) using non-linear regression. All data are expressed as the means of triplicate measurements.

\section{Catalytic products analysis by thin-layer chromatography (TLC)}

The time course of hydrolysis was performed using $10 \mu \mathrm{M}$ enzyme and $2 \%(\mathrm{w} / \mathrm{v})$ substrate at $65^{\circ} \mathrm{C}$. For konjac glucomannan and locust bean gum, $10 \mu \mathrm{l}$ aliquots were taken out at 0 and $90 \mathrm{~min}$ and boiled for $2 \mathrm{~min}$ to stop enzymatic hydrolysis. Whereas for mannooligosaccharides, aliquots were taken out at $0,10,30$, 60 and $90 \mathrm{~min}$ and stop the enzyme activity by boiling. The catalytic products were then analyzed by thin-layer chromatography (TLC) using Silica gel $60 \mathrm{~F}_{254}$ (Merck, Darmstadt, Germany). The expansion solvent used was n-butanol $/ \mathrm{H}_{2} \mathrm{O} /$ acetic acid (2:1:1, by vol). Oligosaccharides were detected by spraying the dried plates with a solution of acetone/diphenylamine/phenylamine/phosphoric acid $(100 \mathrm{ml}: 2 \mathrm{~g}: 2 \mathrm{ml}: 10 \mathrm{ml})$ and heating at $110{ }^{\circ} \mathrm{C}$ for $5 \mathrm{~min}$.

\section{Construction of plasmids for secreted expression in $B$. subtilis}

For constructing the control plasmid pMA5-manA, the mature BcManA-encoding gene without original signal peptide was obtained by PCR using the primer pair of F1 (5'-CGCGGATCCCAAAGCGGCTTTCACGTAAAAG$3^{\prime}$, where the underline indicates the $B a m \mathrm{HI}$ site) and R1 (5'-CTAGCTAGCTTAATCACGTTTGAGCCCATT TTC- $3^{\prime}$, where the underline indicates the NheI site). The PCR program was the same as the construction of plasmid pET28a-manA. The PCR product was purified using a Gel Extraction Kit (OMEGA Bio-tek) and then digested with Bam $\mathrm{HI}$ and NheI for ligation to the pMA5 which were cleaved with the same enzymes. Then the ligation product was transformed into E. coli $\mathrm{DH} 5 \alpha$ cells and plated onto LB agar plates containing $50.0 \mu \mathrm{g} \mathrm{ml}^{-1}$ of ampicillin and incubated at $37{ }^{\circ} \mathrm{C}$ overnight. Besides the original peptide of BcManA, signal peptides including $\mathrm{SP}_{a m y L}, \mathrm{SP}_{\text {lipA }}, \mathrm{SP}_{n p r B}, \mathrm{SP}_{n p r E}, \mathrm{SP}_{\text {lipB }}$ and $\mathrm{SP}_{a m y E}$ from B. subtilis 168 were also used for secreted expression. On the other hand, other two constitutive promoters including $\mathrm{P} 43$ and $\mathrm{P}_{\text {laps }}$, and the inducible promoter of $\mathrm{P}_{\text {grac }}$ were also used for BcManA expression. The fragment lengths of $\mathrm{P} 43$ and $\mathrm{P}_{\text {laps }}$ were $326 \mathrm{bp}$ and $308 \mathrm{bp}$, respectively. $\mathrm{P}_{\text {grac }}$ containing the promoter, lac $\mathrm{O}$ sequences, and the regulator protein lacI was $1548 \mathrm{bp}$ and originated from the plasmid pHT43 plasmid.

The expression plasmids were constructed by PCR using the modified Gibson assembly method [46] base on the plasmid pMA5-manA. Primers used to amplify the signal peptide and promoter fragments for expression plasmid construction were listed in Additional file 1: Tables S1, S2. The I-5 ${ }^{\mathrm{TM}} 2 \times$ High-Fidelity Master Mix (Tsingke Biotech Co., Ltd, China) was used for PCR amplification. The primers for construction of plasmids with different signal peptides directly included the signal peptide sequences and the PCR protocols were as follows: denaturation at $98{ }^{\circ} \mathrm{C}$ for $2 \mathrm{~min}$, followed by 30 cycles of denaturation at $98{ }^{\circ} \mathrm{C}$ for $20 \mathrm{~s}$, annealing at $60{ }^{\circ} \mathrm{C}$ for $20 \mathrm{~s}$ and extension at $72{ }^{\circ} \mathrm{C}$ for $2 \mathrm{~min}$, and a final extension at $72{ }^{\circ} \mathrm{C}$ for $5 \mathrm{~min}$. The plasmid pMA5-manA was used as the template. The PCR product was purified by a Cycle-Pure Kit (OMEGA Bio-tek) and then digested by $D p n \mathrm{I}$ for $6 \mathrm{~h}$. Then $2 \mu \mathrm{l}$ of this the product and $0.5 \mu \mathrm{l}$ of Taq DNA ligase were added into $7.5 \mu$ l of assembly master mixture [46], and this mixture was incubated at $50{ }^{\circ} \mathrm{C}$ for $1 \mathrm{~h}$. Then the product was directly transformed into competent E. coli $\mathrm{DH} 5 \alpha$, and positive colony samples were selected to be further validated by sequencing (Tsingke Biotech Co., Ltd, China).

For the construction of plasmids with different promoters, the PCR amplification program was divided into 
two parts: the amplification of promoter sequence and the pMA5-manA sequence. The primer pairs of F1 and $\mathrm{R} 1, \mathrm{~F} 2$ and R2 in Additional file 1: Table S2 were used for the promoter and pMA5-manA sequences amplification, respectively. The PCR protocol for promoter P43 and $\mathrm{P}_{\text {laps }}$ was as follows: denaturation at $98{ }^{\circ} \mathrm{C}$ for $2 \mathrm{~min}$, followed by 30 cycles of denaturation at $98^{\circ} \mathrm{C}$ for $20 \mathrm{~s}$, annealing at $56{ }^{\circ} \mathrm{C}$ for $20 \mathrm{~s}$ and extension at $72{ }^{\circ} \mathrm{C}$ for $10 \mathrm{~s}$, and a final extension at $72{ }^{\circ} \mathrm{C}$ for $5 \mathrm{~min}$. For the second part of amplification, the PCR protocol was the same as that for construction of plasmids with different signal peptides. All the PCR products were purified by a Cycle-Pure Kit (OMEGA Bio-tek) and then digested by $D p n \mathrm{I}$ for $6 \mathrm{~h}$. Then each $1 \mu \mathrm{l}$ of these corresponding products and $0.5 \mu \mathrm{l}$ of Taq DNA ligase were added into $7.5 \mu \mathrm{l}$ of assembly master mixture followed incubation at $50{ }^{\circ} \mathrm{C}$ for $1 \mathrm{~h}$. Similarly, these reaction products were directly transformed into E. coli $\mathrm{DH} 5 \alpha$ for further validation by sequencing. All the confirmed recombinant pMA5-manA derivative plasmids were than transformed into $B$. subtilis WB600 cells by electroporation transformation as previously [47] for secreted expression in $B$. subtilis.

\section{High-level secreted expression of BcManA in B. subtilis by shake flask}

For gene expression in flask, $0.5 \mathrm{ml}$ of seed culture of $B$. subtilis strains harboring appropriate expression plasmids were inoculated in $50 \mathrm{ml}$ of $2 \times \mathrm{SR}$ medium [5] containing $60.0 \mu \mathrm{g} \mathrm{ml}^{-1}$ of kanamycin and $10 \mu \mathrm{g} \mathrm{ml}^{-1}$ of chloramphenicol in $500 \mathrm{ml}$ flasks. The expression cultivation was performed at $37{ }^{\circ} \mathrm{C}$ with $230 \mathrm{rpm}$. For the determination of cell growth and $\beta$-mannanase production curves, the Horikoshi-I medium (polypeptone $5.0 \mathrm{~g} \mathrm{l}^{-1}$, yeast extract $5.0 \mathrm{~g} \mathrm{l}^{-1}$, glucose $10.0 \mathrm{~g} \mathrm{l}^{-1}, \mathrm{~K}_{2} \mathrm{HO}_{4}$ $1.0 \mathrm{~g} \mathrm{l}^{-1}, \mathrm{MgSO}_{4} \cdot 7 \mathrm{H}_{2} \mathrm{O} 0.2 \mathrm{~g} \mathrm{l}^{-1}, 10 \% \mathrm{Na}_{2} \mathrm{CO}_{3}$ solution $100 \mathrm{ml} \mathrm{l}^{-1}$ ) and modified Horikoshi-I medium (glucose was replaced by $10.0 \mathrm{~g} \mathrm{l}^{-1}$ of locust bean gum) were used for B. clausii S10, while $2 \times$ SR medium was used for $B$. subtilis WB600 and the recombinant $B$. subtilis WB600 containing BcManA gene. The $\mathrm{OD}_{600}$ value was used to indicate cell biomass. The $\beta$-mannanase activity in supernatant and whole cell lysate was assayed under standard condition after cultivation. Furthermore, some cheaper nitrogen source such as soybean powder, peanut meal, peptone, $\mathrm{NH}_{4} \mathrm{Cl}$ and carbon source such as glucose, glycerol, soluble starch, konjac flour, corn starch and dextrin were also used to replace tryptone or yeast extract in $2 \times$ SR medium, respectively. Similarly, $50 \mathrm{ml}$ of different medium in $500 \mathrm{ml}$ flasks was used for the medium component optimization and enzyme yield determination.

\section{Results and discussion}

\section{Gene cloning and sequence analysis of BcManA}

The alkaliphilic strain B. clausii S10 isolated from a soda lake in Inner Mongolia of China showed high $\beta$-mannanase activity under alkaline condition. After screening approximately 4000 clones of the genomic DNA library of $B$. clausii S10, one clone with obvious transparent zone showing positive $\beta$-mannanase activity was obtained (Additional file 2: Fig. S1). Sequence analysis of the plasmid from the positive clone showed an integrated open reading frame (ORF) of $954 \mathrm{bp}$ termed gene manA which encodes a 317-amino-acid protein named $\beta$-mannanase BcManA. The deduced protein sequence of BcManA showed the highest identity of $93 \%$ to the directly submitted endoglucanase sequence from B. clausii (GenBank no. WP_041823522.1) and mannan endo-1,4- $\beta$-mannosidase sequence from $B$. clausii KSM-K16 (GenBank no. BAD62862.1). However, both of these enzymes had not been reported in literature. Meanwhile, BcManA showed high homology to the characterized glycoside hydrolase family 5 mannanases from B. agaradhaerens (UniProtKB/Swiss-Prot G1K3N4.1), Bacillus sp. N16-5 (GenBank no. AAT06599.1), Bacillus sp. JAMB-602 (GenBank no. BAD99527.1), B. circulans CGMCC1554 (GenBank no. AAX87003.1), and B. circulans K-1 (GenBank no. BAA25878.1) with 63, 60, 60, 59, and $58 \%$ identity, respectively (Fig. 1).

In the CAZy database, the members of glycoside hydrolase family 5 have been classified in 56 subfamilies due to the divergent amino acid sequence up to now (http:// www.cazy.org/GH5.html). Based on the sequence comparisons, BcManA belongs to the glycosyl hydrolase family 5, subfamily 8 (GH5_8). As previous study, eight conserved residues of all family 5 enzymes were demonstrated to be responsible for the catalytic activity [10]. The multiple sequence alignment showed that these essential active residues were also conserved in BcManA as R79, H115, N153, D154, H219, Y221, D249 and W278 (Fig. 1). Among these residues, the aspartate residues D154 and D249 are suggested to be the proton donor and the nucleophile, which was consistent with D158 and D254 in BSP165MAN belonging to GH5_8, respectively [48]. Frequently, $\beta$-mannanases carry extra non-catalytic modules which generally are the carbohydrate binding modules (CBMs) besides the catalytic module [1]. The CBM are thought to enhance enzyme activity toward cellulose conjugated mannan. However, no obvious CBM modules were found in BcManA or the five high homologous mannanases by the sequence analysis. Moreover, as an extracellular enzyme, the BcManA protein also includes a typical amino-terminal signal sequence with 28 amino acids (Fig. 1), which revealed that the BcManA mature protein contained 289 amino acids and had a 


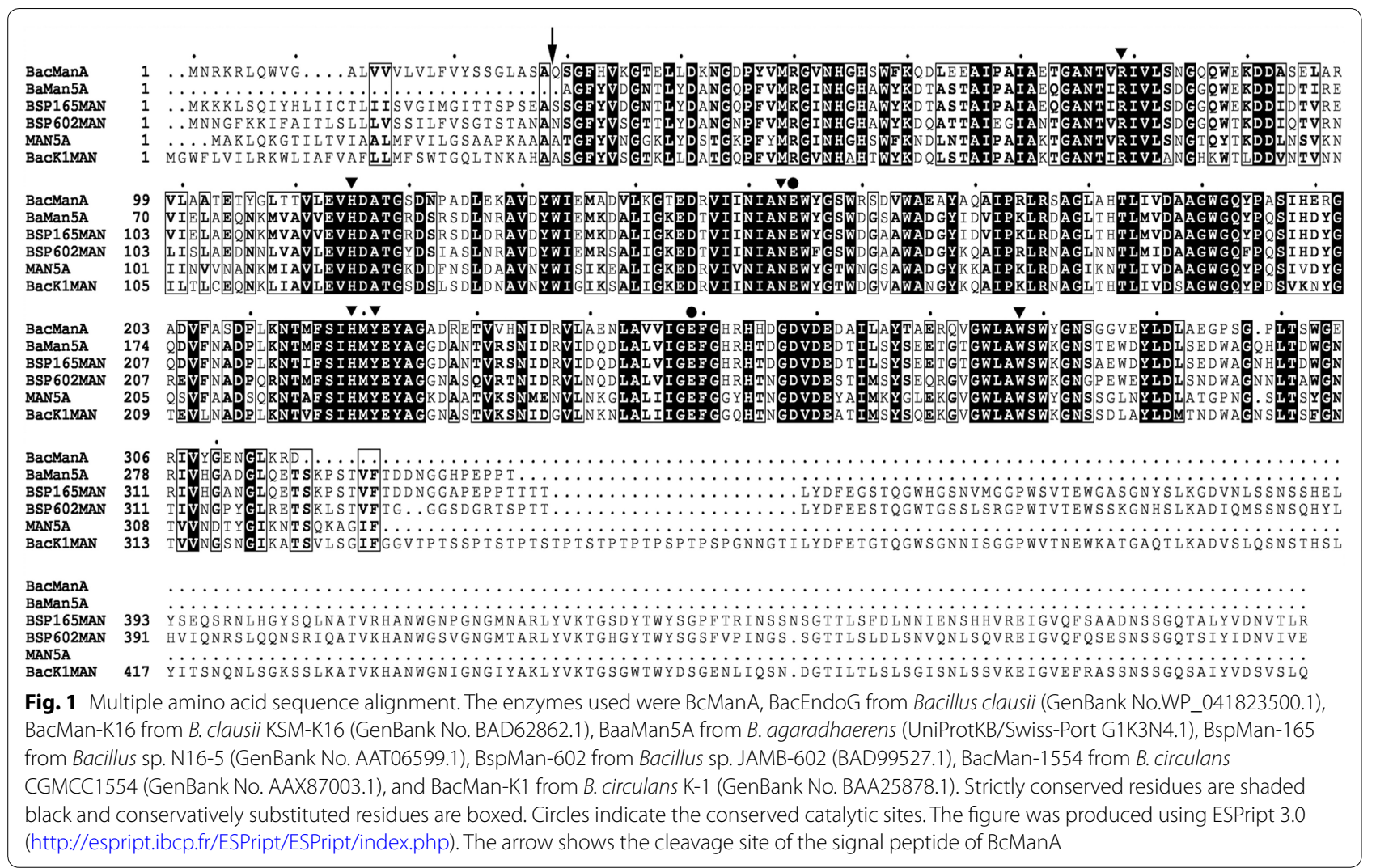

calculated molecular mass of $34.3 \mathrm{kDa}$ and an isoelectric point of 4.6.

\section{Expression in E. coli and purification of recombinant BcManA}

Using the shake-flask cultivation in LB medium, the total activity of the mature BcManA reached $343 \mathrm{U} \mathrm{ml}^{-1}$ with extracellular activity of $5 \mathrm{U} \mathrm{ml}^{-1}$ after $5 \mathrm{~h}$ induction using locus bean gum as substrate. The recombinant enzyme was purified by the above twostep process with a recovery activity of $40.9 \%$ and a final purity of about $97.5 \%$. SDS-PAGE analysis showed that the purified recombinant mature BcManA has a molecular mass about $34 \mathrm{kDa}$ (Fig. 2) which was consistent with the calculated molecular weight of $34.3 \mathrm{kDa}$. The reported Bacillus $\beta$-mannanases showed the majority of molecular mass from 30 to $70 \mathrm{kDa}$ (Table 2). The smallest and largest $\beta$-mannanases reported to date were found to be $22 \mathrm{kDa}$ and $130 \mathrm{kDa}$ from $B$. halodurans PPKS-2 and Bacillus sp. JAMB-750, respectively $[49,50]$. Moreover, after heating at $60{ }^{\circ} \mathrm{C}$ for $20 \mathrm{~min}$, almost no BcManA activity loss was found, while most

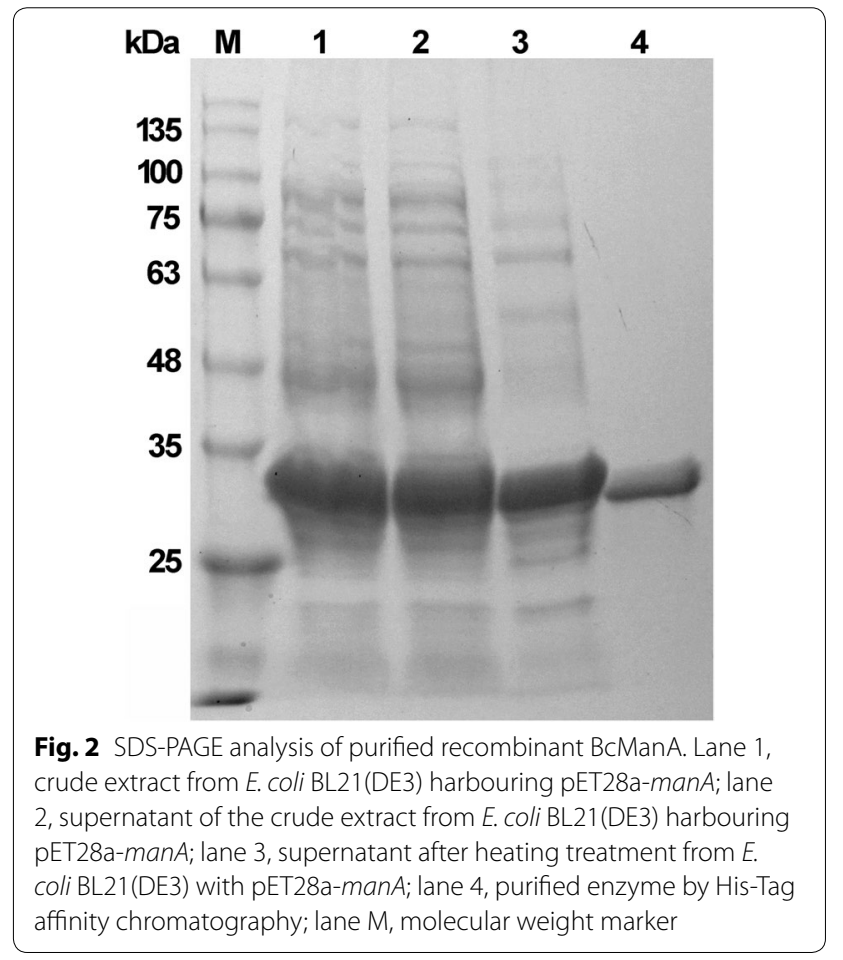


Table 2 Physicochemical properties of characterized Bacillus $\boldsymbol{\beta}$-mannanases

\begin{tabular}{|c|c|c|c|c|c|c|c|c|}
\hline \multirow[t]{2}{*}{ Bacteria strain } & \multirow[t]{2}{*}{ Mol. wt (kDa) } & \multicolumn{2}{|c|}{ Optimum } & \multicolumn{2}{|l|}{ Stability } & \multirow{2}{*}{$\begin{array}{l}\text { Substrate } \\
\text { preferred }\end{array}$} & \multirow{2}{*}{$\begin{array}{l}\text { Specific activity } \\
\left(\mathrm{U} \mathrm{mg}^{-1}\right)\end{array}$} & \multirow[t]{2}{*}{ References } \\
\hline & & $\mathrm{pH}$ & Temp & $\mathrm{pH}$ & Temp & & & \\
\hline B. clausii S10 & 34 & 9.5 & 75 & $7.0-11.5$ & $\leq 70$ & KGM & 2366.2 & This work \\
\hline B. subtilis CSB31 & 47 & 12.5 & 60 & $5.8-12.5$ & $\leq 65$ & LBG & 1796.1 & {$[53]$} \\
\hline B. halodurans PPKS-2 & 22 & 11.0 & 70 & $8.0-12.0$ & $\leq 70$ & CG & 776.0 & [49] \\
\hline Bacillus sp. JAMB-750 & 130 & 10.0 & 55 & $6.0-10.5$ & $\leq 50$ & LBG & 36.3 & [50] \\
\hline B. cereus N1 & 63 & 10.0 & 50 & NA & NA & NA & 628.3 & [54] \\
\hline Bacillus sp. N16-5 & 55 & 9.5 & 70 & $8.5-10.0$ & $\leq 60$ & LBG & 5065.0 & [10] \\
\hline Bacillus sp. JAMB-602 & 50 & 9.0 & 65 & $6.0-11.0$ & $\leq 50$ & LBG & 287.0 & [9] \\
\hline Bacillus sp. AM-001 & 58 & 9.0 & 60 & $8.0-9.0$ & $\leq 50$ & NA & NA & [74] \\
\hline B. nealsonii PN-11 & 50 & 8.8 & 65 & $5.0-10.0$ & $\leq 70$ & LBG & 2288.9 & [13] \\
\hline B. circulans CGMCC 1554 & 32 & 7.6 & 60 & $6.0-10.0$ & $\leq 50$ & LBG & 4839.0 & [51] \\
\hline B. circulans CGMCC 1416 & 31 & 7.6 & 58 & $7.0-9.0$ & $\leq 50$ & LBG & 481.6 & [12] \\
\hline Bacillus sp. CSB39 & 30 & 7.5 & 70 & $4.6-11.0$ & $\leq 70$ & LBG & 1063.9 & [68] \\
\hline Bacillus sp. W-2 & 36 & 7.0 & 70 & $5.0-10.0$ & $\leq 60$ & LBG & 710.0 & [7] \\
\hline B. subtilis BCC41051 & 38 & 7.0 & 60 & $5.0-11.5$ & $\leq 60$ & NA & 3169.0 & [76] \\
\hline B. licheniformis DSM13 & 45 & 7.0 & 50 & $6.0-9.0$ & $\leq 55$ & KGM & 1672.0 & [37] \\
\hline B. licheniformis & NA & 7.0 & 60 & $5.0-9.0$ & $\leq 60$ & LBG & 4341.0 & [8] \\
\hline B. subtilis $\mathrm{H} 5$ & 37 & 7.0 & 55 & $6.0-7.5$ & $\leq 45$ & NA & 1900.0 & [72] \\
\hline B. circulans M-21 & 33 & 7.0 & 50 & $6.0-9.0$ & $\leq 40$ & KGM & $19,373.3^{\mathrm{a}}$ & [65] \\
\hline B. circulans K-1 & 62 & 6.9 & 65 & NA & NA & KGM & 3100.0 & [52] \\
\hline B. stearothermophilus & 76 & 6.5 & 70 & NA & $\leq 70$ & LBG & 100.0 & [6] \\
\hline B. pumilus GBSW19 & 44 & 6.5 & 65 & $5.0-11.0$ & $\leq 60$ & LBG & 1021.0 & [14] \\
\hline Bacillus sp. HJ14 & 40 & 6.5 & 65 & $5.0-10.0$ & $\leq 60$ & LBG & 443.4 & [70] \\
\hline Bacillus sp. MG-33 & NA & 6.5 & 65 & 6.5 & $\leq 60$ & LBG & 591.7 & [69] \\
\hline B. subtilis G1 & 41 & 6.5 & 45 & $5.0-9.0$ & $\leq 50$ & LBG & 2718.0 & [80] \\
\hline B. subtilis YH12 & 40 & 6.5 & 55 & $4.5-8.0$ & $\leq 60$ & LBG & 7302.4 & [71] \\
\hline B. subtilis B36 & 38 & 6.4 & 50 & $5.0-8.0$ & $\leq 60$ & LBG & 927.8 & [11] \\
\hline B. subtilis BE-91 & 28 & 6.0 & 65 & $4.5-7.0$ & $\leq 70$ & KGM & 79.9 & [62] \\
\hline Bacillus sp. SWU60 & 38 & 6.0 & 60 & $5.0-9.0$ & $\leq 60$ & KGM & 14.0 & [63] \\
\hline B. subtilis TBS2 & 42 & 6.0 & 60 & $2.0-8.0$ & $\leq 100$ & LBG & 1653.0 & [60] \\
\hline B. subtilis WL-3 & 38 & 6.0 & 60 & NA & $\leq 60$ & LBG & 5900.0 & [43] \\
\hline B. subtilis MAFIC-S11 & 40 & 6.0 & 50 & $2.0-7.0$ & $<60$ & LBG & 3706.0 & [42] \\
\hline B. circulans NT 6.7 & 40 & 6.0 & 50 & NA & NA & LBG & 295.0 & [38] \\
\hline B. subtilis WY34 & 40 & 6.0 & 65 & $5.5-10.1$ & $\leq 60$ & LBG & 8302.4 & [67] \\
\hline B. subtilis WL-7 & 38 & 6.0 & 55 & $4.5-9.0$ & $\leq 60$ & LBG & $10,080.0$ & [73] \\
\hline Bacillus sp. MSJ-5 & 41 & 5.5 & 50 & $5.0-9.0$ & $\leq 65$ & LBG & 5383.0 & {$[55]$} \\
\hline B. subtilis NM-39 & 38 & 5.0 & 55 & $4.0-9.0$ & $\leq 55$ & LBG & 108.0 & {$[56]$} \\
\hline
\end{tabular}

NA data not available

a The activity was defined as the amount of enzyme that released $1 \mu \mathrm{g}$ reducing sugar from mannan per minute

of the E. coli proteins were denatured, which indicated that an appropriate heat treatment is efficient for the purification process. The specific activity of the purified BcManA was 2087.1 and $2366.2 \mathrm{U} \mathrm{mg}^{-1}$ with locust bean gum and konjac glucomannan as substrate, respectively. This activity was lower than the homologous $\beta$-mannanases of BSP165MAN from Bacillus sp. N16-5 (5065.0 $\mathrm{U} \mathrm{mg}^{-1}$ ) [10], MAN5A from B. circulans
CGMCC1554 (4839.0 $\mathrm{U} \mathrm{mg}^{-1}$ ) [51] and BacK1MAN from B. circulans $\mathrm{K}-1$ (3140.0 $\mathrm{U} \mathrm{mg}^{-1}$ ) [52], but higher than BSP602MAN from Bacillus sp. strain JAMB-602 $\left(287.0 \mathrm{U} \mathrm{mg}^{-1}\right)$ [9]. In addition, although there are some $\beta$-mannanases which specific activity was higher than BcManA, the specific activity of BcManA was still higher than most other reported alkaline and Bacillus $\beta$-mannanases (Table 2). 


\section{Biochemical characterization of recombinant BcManA}

The effect of $\mathrm{pH}$ and temperature on the recombinant BcManA was studied using locust bean gum as substrate. The recombinant BcManA had a $\mathrm{pH}$ optimum at 9.5 which was similar to $\beta$-mannanases from Bacillus sp. N16-5 [10] and Bacillus sp. strain JAMB-602 [9] but lower than those extreme alkaline enzymes from Streptomyces sp. CS428 (pH 12.5) [22], B. subtilis subsp. inaquosorum CSB31 (pH 12.5) [53], B. halodurans PPKS-2 (pH 11.0) [49], Bacillus sp. JAMB-750 (pH 10.0) [50] and $B$. cereus $\mathrm{N} 1$ ( $\mathrm{pH} 10.0)$ [54]. By setting the activity at $\mathrm{pH}$ 9.5 as $100.0 \%$, BcManA showed relative high activity at pH 7.0-10.5 and more than $50.0 \%$ of full activity was retained at that $\mathrm{pH}$ range. However, the relative activity declined rapidly at $\mathrm{pH}$ below 6.5 or above 10.5 . There was only $32.5 \%$ and $34.1 \%$ of relative activity at $\mathrm{pH} 6.0$ and 11.0 (Fig. 3a). BcManA was stable over an alkaline
$\mathrm{pH}$ range from 6.0 to 11.5 (Fig. 3b), in which more than $55.0 \%$ of the original enzyme activity was retained after $6 \mathrm{~h}$ at $30^{\circ} \mathrm{C}$. However, the residual activity declined certainly when the $\mathrm{pH}$ values were lower than 5.5 or higher than 11.5 , and only $20.5 \%$ and $25.8 \%$ of original activity was retained after pretreatment at $\mathrm{pH} 5.0$ and 12.0, respectively (Fig. $3 \mathrm{~b}$ ). These indicated that BcManA was a typical moderate alkaline $\beta$-mannanase. An extremely alkaline mannanase (MnB31) from B. subtilis subsp. inaquosorum CSB31 was found to have the highest optimal $\mathrm{pH}$ of 12.5 and to be stable at $\mathrm{pH}$ range from 5.8 to 12.5 , which was the most alkaline $\beta$-mannanase reported to date [53]. In addition, almost all the reported Bacillus $\beta$-mannanases displayed optimal $\mathrm{pH}$ at the range from 6.0 to 12.5 (Table 2), which indicated that Bacillus strains were the main sources of neutral and alkaline $\beta$-mannanases. Only the $\beta$-mannanases from Bacillus
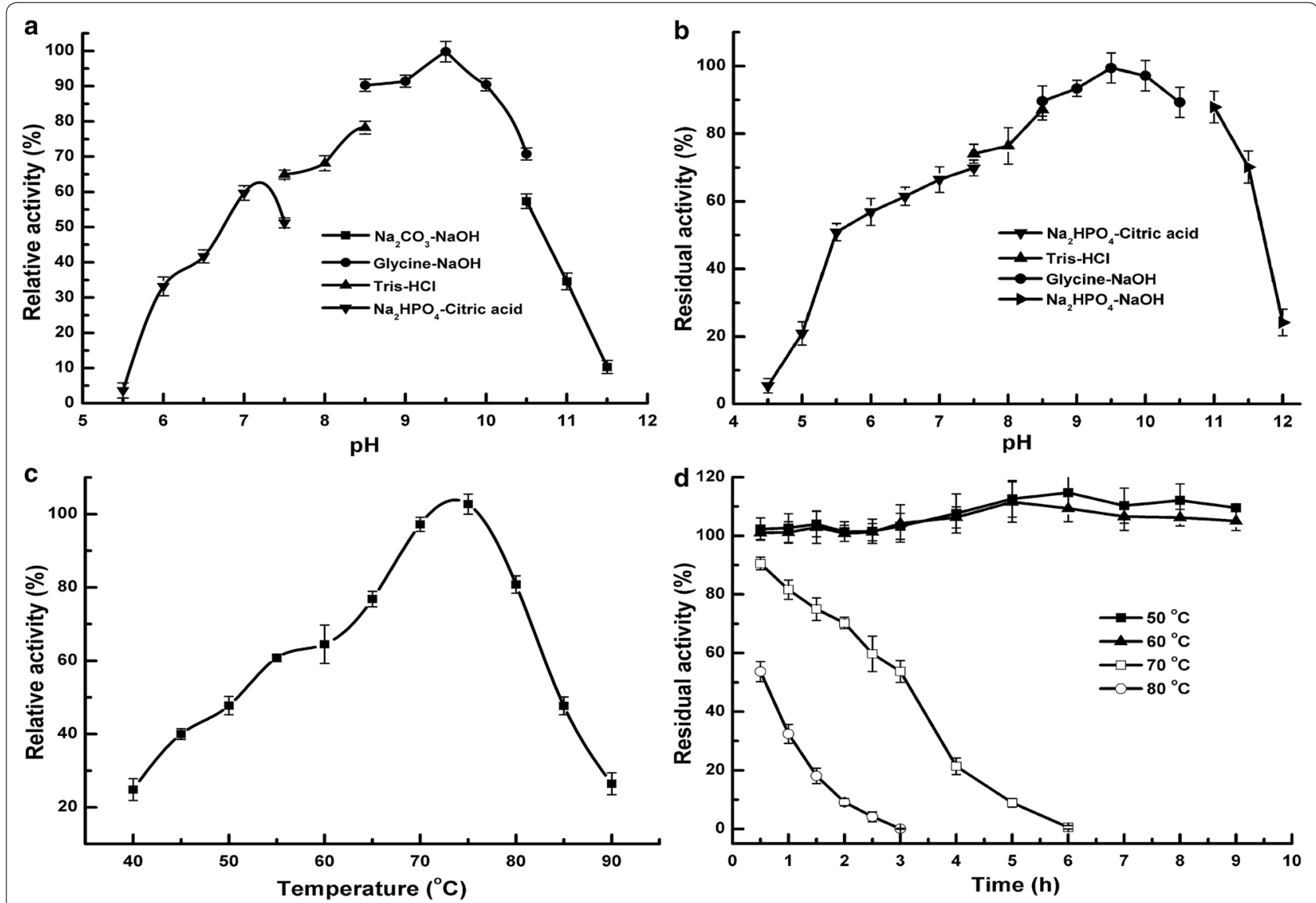

Fig. $3 \mathrm{pH}$ and temperature profiles of the purified recombinant BcManA. a Optimal pH: the buffer used was $50 \mathrm{mM} \mathrm{Na}_{2} \mathrm{HPO}_{4}-\mathrm{Citric}$ acid buffer (pH 5.5-7.5, black down-pointing triangle), 50 mM Tris-HCl buffer ( $\mathrm{pH} 7.5-8.5$, black up-pointing triangle), $50 \mathrm{mM}$ glycine-NaOH buffer ( $\mathrm{pH} 8.5-10.5$, black circle) and $25 \mathrm{mM} \mathrm{Na}_{2} \mathrm{CO}_{3}-\mathrm{NaOH}$ buffer ( $\mathrm{pH}$ 10.5-11.5, black square); b pH stability: the buffer with different pH was $50 \mathrm{mM} \mathrm{Na}_{2} \mathrm{HPO}_{4}-\mathrm{Citric}$ acid buffer ( $\mathrm{pH} 4.5-7.5$, black down-pointing triangle), $50 \mathrm{mM}$ Tris- $\mathrm{HCl}$ buffer ( $\mathrm{pH} 7.5-8.5$, black up-pointing triangle), $50 \mathrm{mM}$ glycine- $\mathrm{NaOH}$ buffer ( $\mathrm{pH}$ 8.5-10.5, black circle) and $\mathrm{Na}_{2} \mathrm{HPO}_{4}-\mathrm{NaOH}$ buffer ( $\mathrm{pH}$ 11.0-12.0, black right-righting pointer); c optimal temperature; $\mathbf{d}$ thermal stability: the enzyme was incubated at $50^{\circ} \mathrm{C}$ (black square), $60^{\circ} \mathrm{C}$ (black up-pointing triangle), $70{ }^{\circ} \mathrm{C}$ (white square) and $80^{\circ} \mathrm{C}$ (white circle) in $50 \mathrm{mM} \mathrm{glycine-}$ $\mathrm{NaOH}$ buffer ( $\mathrm{pH}$ 9.0). All of the activities were measured under standard enzyme assay conditions with locust bean gum as the substrate. Values are expressed as the means of three experiments. Error bars represent standard deviations 
sp. MSJ-5 [55] and B. subtilis NM-39 [56] showed certain acidic enzymatic characteristics. Relative to neutral and alkaline $\beta$-mannanases, acidic $\beta$-mannanases mostly come from fungus, such as those from Penicillium oxalicum GZ-2 [30], Neosartorya fischeri P1 [32], Aspergillus niger LW-1 [29], Gloeophyllum trabeum [57], Phialophora sp. p13 [58], and Bispora sp. MEY-1 [59] showing optimal $\mathrm{pH}$ of $4.0,4.0,3.5,2.5,1.5,1.5$, respectively.

Generally, most of reported $\beta$-mannanases showed optimal temperature of $40-75{ }^{\circ} \mathrm{C}$ [60]. There were only few $\beta$-mannanases that had optimal temperature above $75{ }^{\circ} \mathrm{C}$, such as Man5 from Thermotoga maritime [18], MAN-P from A. niger [61], rMan5P1 from $N$. fischeri [32], Man5XZ3 from $A$. nidulans XZ3 [25], and ManBK01 from A. niger BK01 [27]. Man5 had optimal temperature of $90{ }^{\circ} \mathrm{C}$ which was the highest reported to date, whereas the other four fungus $\beta$-mannanases showed the highest activity at $80{ }^{\circ} \mathrm{C}$. The optimal temperature of BcManA was $75^{\circ} \mathrm{C}$ and more than $40.0 \%$ of the activity was maintained in the range of $50-85^{\circ} \mathrm{C}$ (Fig. 3c). Although this optimal reaction temperature was lower than those five thermostable $\beta$-mannanases with $\mathrm{pH}$ optimum of 4.0 7.0, it was still the highest of all reported Bacillus and alkaline $\beta$-mannanases including the four highly homologous enzymes (Table 2). Previous research indicated that most $\beta$-mannanases were stable at temperatures equal or less than $60{ }^{\circ} \mathrm{C}$ and the enzyme activity decreased rapidly at higher temperatures [60]. The BcManA showed good thermostability and almost no activity loss was found after $9 \mathrm{~h}$ incubation at $50{ }^{\circ} \mathrm{C}$ and $60{ }^{\circ} \mathrm{C}$ (Fig. 3d). Actually, no obvious activity loss was detected even after incubating BcManA at $50{ }^{\circ} \mathrm{C}$ for $52 \mathrm{~h}$ (data not shown). For incubation at $60{ }^{\circ} \mathrm{C}$, the obvious activity loss appeared after incubation for more than $36 \mathrm{~h}$, and about $68.1 \%$ of the original activity retained after incubation for $48 \mathrm{~h}$. There was even about $80.0 \%$ and more than $50.0 \%$ of the original activity retained after incubation at $70{ }^{\circ} \mathrm{C}$ for $1 \mathrm{~h}$ and $3 \mathrm{~h}$, respectively. The residual activity decreased rapidly when incubation at $80{ }^{\circ} \mathrm{C}$ and only about $50.0 \%$ and $32.0 \%$ activity retained after 0.5 and $1 \mathrm{~h}$ incubation, respectively. Although the three fungi $\beta$-mannanases including rMan5P1, Man5XZ3 and ManBK01 had higher optimal temperature, they showed less thermostability than BcManA. Only $50.0 \%$ activity was retained after incubating rMan5P 1 at $70{ }^{\circ} \mathrm{C}$ for $10 \mathrm{~min}$ [32]. Meanwhile, about $70.0 \%$ activity of Man5XZ3 retained after $180 \mathrm{~min}$ incubation at $60{ }^{\circ} \mathrm{C}$ [25], whereas only $50.0 \%$ activity of ManBK01 retained after $15 \mathrm{~min}$ incubation at $80{ }^{\circ} \mathrm{C}$ [27]. Only MAN-P showing $61.0 \%$ residual activity after incubation at $80{ }^{\circ} \mathrm{C}$ for $120 \mathrm{~min}$ [61] and Man5 with half-life of $38 \mathrm{~min}$ at $90{ }^{\circ} \mathrm{C}$ [18] displayed better thermostability than BcManA. Furthermore, by comparison with other $\beta$-mannanases, the thermostability of BcManA was also better than all reported alkaline $\beta$-mannanases and most of Bacillus $\beta$-mannanases (Table 2) except for that from B. subtilis TBS2 which showed about $60 \%$ activity retained at $80{ }^{\circ} \mathrm{C}[60]$. $\beta$-mannanases have many applications in the industrial processes, such as paper industry, food industry, oil drilling, detergent industry, hydrolysis of coffee extract, textile and cellulosic fiber processing industry [1]. Among these applications, the activity and stability of $\beta$-mannanase at alkaline and thermal condition was crucial especially for enzymatic breaking of hydraulic fracturing fluids in oil drilling industry, biobleaching of pulp and paper in the paper industry, and enzymatic scouring and desizing processes in the textile industry [10,34]. Overall consideration of $\mathrm{pH}$ and temperature performance, $\mathrm{BcManA}$ distinguished from other reported $\beta$-mannanases and was a promising thermoalkaline $\beta$-mannanase for potential industrial application.

The effect of metal ions and chemicals on the activity of BcManA was evaluated under standard condition (Table 3). $\mathrm{Hg}^{2+}, \mathrm{Pb}^{2+}, \mathrm{Ag}^{+}, \mathrm{Zn}^{2+}, \mathrm{Fe}^{2+}$, and $\mathrm{Fe}^{3+}$ strongly inhibited the activity of BcManA, whereas $\mathrm{Cu}^{2+}, \mathrm{Mn}^{2+}$, $\mathrm{Ni}^{2+}$ and $\mathrm{Co}^{2+}$ partially inhibited BcManA. Heavy metal irons are known to have strong affinities for sulfhydryl (-SH) groups and normally act as an irreversible inhibitor for enzyme activity. Similarly, heavy metal irons such as $\mathrm{Ag}^{2+}$ and $\mathrm{Hg}^{2+}$ also strongly inhibited activity of other highly homologous $\beta$-mannanases except for BacK$1 \mathrm{MAN}$ which activity was not affected by $\mathrm{Ag}^{2+}$ [52]. Furthermore, $\mathrm{Pb}^{2+}$ showed strong inhibition to BcManA and BSP602MAN but no affection on BSP165MAN $[9,10]$. Also $\mathrm{Fe}^{2+}$ and $\mathrm{Fe}^{3+}$ which strongly inhibited BcManA just showed unobvious affection on BSP165MAN and BacK1MAN [10, 52]. The other tested metal ions and

\section{Table 3 Effects of metal ions and reagents on BcManA} activity

\begin{tabular}{lrll}
\hline Compound (1 mM) & $\begin{array}{l}\text { Relative } \\
\text { activity (\%) }\end{array}$ & Compound (1 mM) & $\begin{array}{l}\text { Relative } \\
\text { activity } \\
\text { (\%) }\end{array}$ \\
\hline Control & 100.0 & $\mathrm{Co}^{2+}$ & 32.0 \\
$\mathrm{Cu}^{2+}$ & 75.1 & $\mathrm{Fe}^{3+}$ & 0.0 \\
$\mathrm{Fe}^{2+}$ & 1.5 & $\mathrm{Rb}^{+}$ & 105.7 \\
$\mathrm{Hg}^{2+}$ & 0.0 & $\mathrm{Cs}^{+}$ & 92.1 \\
$\mathrm{Mg}^{2+}$ & 108.4 & $\mathrm{~K}^{+}$ & 97.4 \\
$\mathrm{Mn}^{2+}$ & 44.8 & $\mathrm{Na}^{+}$ & 98.3 \\
$\mathrm{Ni}^{2+}$ & 22.1 & $\mathrm{EDTA}$ & 144.0 \\
$\mathrm{~Pb}^{2+}$ & 1.0 & $\mathrm{SDS}(1 \%)$ & 106.2 \\
$\mathrm{Zn}^{2+}$ & 1.1 & $\mathrm{Urea}(5 \mathrm{M})$ & 122.7 \\
$\mathrm{Ag}^{+}$ & 0.0 & $\mathrm{GH}(1 \mathrm{M})$ & 20.5 \\
$\mathrm{Ca}^{2+}$ & 112.3 & - & - \\
\hline $\mathrm{GH}^{2+}$ & & \\
\hline
\end{tabular}

GH guanidine hydrochloride 
SDS did not markedly affect BcManA activity except for $\mathrm{Ca}^{2+}$ which activated the activity about $12.3 \%$. Different from BcManA, the activity of MAN5A was strongly inhibited by SDS [51]. BcManA also showed good tolerance to EDTA and urea, with about $44.0 \%$ and $22.7 \%$ activation obtained after treatment with $1.0 \mathrm{mM}$ EDTA and $5.0 \mathrm{M}$ urea at $30{ }^{\circ} \mathrm{C}$ for $30 \mathrm{~min}$, respectively (Table 3 ). Differently, only $27.0 \%$ original activity of MAN5A was retained after incubation with $1 \mathrm{mM}$ EDTA [51]. However, BcManA was sensitive to guanidine hydrochloride and only $20.5 \%$ activity retained following incubation in 1.0 M guanidine hydrochloride (Table 3 ).

\section{Substrate specificity and kinetic parameters}

The hydrolytic activity of the recombinant BcManA towards various substrates was evaluated at $75^{\circ} \mathrm{C}$ and $\mathrm{pH}$ 9.5. BcManA showed substantial activity towards polysaccharides containing $\beta$-1,4-mannosidic linkages such as konjac glucomannan (KGM), locust bean gum (LBG), guar gum (GG) and sesbania gum (SG), but no activity was observed towards carboxymethyl cellulose, xylan, glucan, pectin, chitin, soluble starch, or $\alpha$-1,6-linked yeast mannan. Also, BcManA showed no activity on p-nitrophenyl $\beta$ - and $\alpha$-mannosides, $\beta$ - and $\alpha$-galactosides, and $\beta$ - and $\alpha$-glucosides, which indicated that BcManA was unable to cleave terminal mannosides. As shown in Table 4, the highest activity of $2366.2 \mathrm{U} \mathrm{mg}^{-1}$ was obtained towards konjac glucomannan. BcManA also showed about $88.2 \%$ activity on LBG relative to KGM (taken as $100.0 \%$ ), whereas the activity on SG and GG was only $26.0 \%$ and $18.1 \%$ relative to that on KGM, respectively. KGM is a glucomannan with glucose/mannose ratio of $1: 1.6$, whereas LBG and SG (or GG) are galactomannan with a galactose/mannose ratio of $1: 4$ and $1: 2$, respectively [1]. This indicated that the BcManA activity seems to be limited by the side group substitution of substrates and BcManA prefers to catalyze mannan substrates with lower substitution rate. Similar specificity was also found in some $\beta$-mannanases such as those from B. circulans K-1 [52], B. subtilis BE-91 [62], B. licheniformis DSM13 [37], Bacillus sp. MSJ-5 [55], Bacillus sp. SWU60 [63], and Reinekea sp. KIT-YO10 [64] except for those enzymes from B. licheniformis DSM13, Bacillus sp.
SWU60 and $B$. circulans $\mathrm{K}-1$ showing almost no activity on guar gum. However, most of reported Bacillus $\beta$-mannanases including the five enzymes showing high sequence identity with BcManA still showed the highest activity towards LBG instead of KGM (Table 2).

The $K_{m}$ values of BcManA for KGM, LBG, GG and SG were $0.62,1.68,3.16$ and $5.56 \mathrm{~g} \mathrm{l}^{-1}$, resulting in $k_{\text {cat }} / K_{m}$ values of $1998.2,819.1,34.8$ and $29.2 \mathrm{l} \mathrm{s}^{-1} \mathrm{~g}^{-1}$, respectively (Table 4), which further confirming the preferred activity towards KGM over the other substrates tested. For substrate KGM, BcManA showed a $K_{m}$ value which was similar to $\beta$-mannanase from $A$. niger BK01 (0.60 $\left.\mathrm{g} \mathrm{l}^{-1}\right)$ [27] but lower than that of other $\beta$-mannanases including those from Phialophora sp. P13 (1.30 $\mathrm{g} \mathrm{l}^{-1}$ ) [58], Reinekea sp. KIT-YO10 (1.60 $\left.\mathrm{g} \mathrm{l}^{-1}\right)$ [64], B. subtilis BE-91 (1.75 $\mathrm{g} \mathrm{l}^{-1}$ ) [62], P. oxalicum GZ-2 (2.10 $\left.\mathrm{g} \mathrm{l}^{-1}\right)$ [30], Bispora sp. MEY-1 (2.63 $\left.\mathrm{g} \mathrm{l}^{-1}\right)$ [59], P. pinophilum C1 (4.80 $\left.\mathrm{g} \mathrm{l}^{-1}\right)$ [66], Bacillus sp. MSJ-5 (7.50 $\left.\mathrm{g} \mathrm{l}^{-1}\right)$ [55], B. subtilis WY34 (10.50 $\left.\mathrm{g} \mathrm{l}^{-1}\right)$ [67], and $B$. licheniformis DSM13 (14.9 $\left.\mathrm{g} \mathrm{l}^{-1}\right)$ [37]. This indicated that BcManA had higher substrate affinity and maximum catalytic efficiency at low KGM concentration. Although the $K_{m}$ value of BcManA for the standard substrate LGB was higher than that of some $\beta$-mannanases from $B$. subtilis subsp. inaquosorum CSB31 (0.043 $\left.\mathrm{g} \mathrm{l}^{-1}\right)$ [53], Bacillus sp. CSB39 (0.082 $\left.\mathrm{g} \mathrm{l}^{-1}\right)$ [68], Bacillus sp. MG-33 (0.20 $\left.\mathrm{g} \mathrm{l}^{-1}\right)$ [69], N. fischeri P1 (0.83 $\left.\mathrm{g} \mathrm{l}^{-1}\right)$ [32], A. nidulans XZ3 $\left(0.90 \mathrm{~g} \mathrm{l}^{-1}\right)$ [25], Streptomyces sp. CS428 (1.01 $\left.\mathrm{g} \mathrm{l}^{-1}\right)$ [22], and $A$. niger LW-1 (1.10 $\left.\mathrm{g} \mathrm{l}^{-1}\right)$ [29], it was also lower than that of most reported $\beta$-mannanases such as those from Bacillus sp. HJ14 (2.20 $\left.\mathrm{g} \mathrm{l}^{-1}\right)$ [70], Phialophora sp. P13 (2.50 $\left.\mathrm{g} \mathrm{l}^{-1}\right)$ [58], Bacillus sp. JAMB-602 (3.10 $\left.\mathrm{g} \mathrm{l}^{-1}\right)$ [9], B. halodurans PPKS-2 (3.85 $\mathrm{g}^{-1}$ ) [49], P. pinophilum C1 (5.60 $\left.\mathrm{g} \mathrm{l}^{-1}\right)$ [66], B. subtilis BE-91 (7.14 $\left.\mathrm{g} \mathrm{l}^{-1}\right)$ [62], B. nealsonii PN-11 (7.22 $\left.\mathrm{g} \mathrm{l}^{-1}\right)$ [13], B. subtilis WY34 (7.60 $\left.\mathrm{g} \mathrm{l}^{-1}\right)$ [67], B. subtilis MAFIC-S11 (8.00 $\mathrm{g} \mathrm{l}^{-1}$ ) [42], Bacillus sp. MSJ-5 (11.67 $\left.\mathrm{g} \mathrm{l}^{-1}\right)$ [55], and B. subtilis YH12 (30.00 $\left.\mathrm{g} \mathrm{l}^{-1}\right)$ [71]. This indicated that BcManA also showed high LBG affinity among the reported $\beta$-mannanases. In addition, BcManA showed a high $k_{\text {cat }}$ value of $1238.9 \mathrm{~s}^{-1}$ for KGM which was only lower than that of MAN5 from Bacillus sp. MSJ-5 $\left(3.8 \times 10^{4} \mathrm{~s}^{-1}\right)$ which was an acidic and

Table 4 Substrate specificity and kinetic parameters of BcManA

\begin{tabular}{|c|c|c|c|c|c|}
\hline Substrate & $\begin{array}{l}\text { Specific activity } \\
\left(\mathrm{U} \mathrm{mg}^{-1}\right)\end{array}$ & $\begin{array}{l}\text { Relative activity } \\
(\%)\end{array}$ & Mean $K_{m}\left(\mathrm{gl}^{-1}\right) \pm S D$ & Mean $k_{\text {cat }}\left(s^{-1}\right) \pm S D$ & $\begin{array}{l}\text { Mean } k_{\text {cat }} / K_{m} \\
\left(I s^{-1} g^{-1}\right) \pm S D\end{array}$ \\
\hline Konjac glucomannan & 2366.2 & 100.0 & $0.62 \pm 0.05$ & $1238.9 \pm 13.2$ & $1998.2 \pm 21.4$ \\
\hline Locust bean gum & 2087.1 & 88.2 & $1.68 \pm 0.04$ & $1376.1 \pm 15.1$ & $819.1 \pm 25.7$ \\
\hline Guar gum & 428.3 & 18.1 & $3.16 \pm 0.06$ & $109.9 \pm 2.5$ & $34.8 \pm 1.3$ \\
\hline Sesbania gum & 615.2 & 26.0 & $5.56 \pm 0.11$ & $164.7 \pm 2.9$ & $29.2 \pm 1.1$ \\
\hline
\end{tabular}


mesophilic $\beta$-mannanase. Higher $k_{c a t}$ value indicates its better hydrolytic efficiency [52]. Therefore, BcManA not only showed the highest KGM affinity but also was more catalytically efficient for KGM than other reported alkaline and thermostable $\beta$-mannanases.

\section{Analysis of hydrolysis product by TLC}

The hydrolysis products from LBG and KGM by BcManA were analyzed by TLC. A mixture of mannose oligosaccharides consisting of mannose (M1), mannobiose (M2), mannotriose (M3), mannotetraose (M4), mannopentose (M5), and mannohexose (M6) were used as standard markers. As shown in Fig. 4a, the products hydrolysed from LBG to KGM were mainly oligosaccharides with various sizes after 90 in cumulative action, which indicated that BcManA was an endo-acting $\beta$-mannanase. In addition, small amount of mannose was also found in the hydrolysed products, which was similar to the $\beta$-mannanases from Bacillus sp. N16-5 [10], Bacillus sp. W-2 [7], B. subtilis YH12 [71], B. subtilis BS5 [41], B. subtilis WL-3 [43], B. subtilis NM-39 [56], B. circulans
CGMCC1554 [51], Bacillus sp. MG-33 [69] and B. subtilis $5 \mathrm{H}$ [72], but different from those from B. subtilis WY34 [67] and B. subtilis subsp. inaquosorum CSB31 [53] which did not produce mannose.

The catalytic activity of BcManA on the manno-oligosaccharides was also assayed. BcManA showed no activity on M2 (Fig. 4b) and very low activity on M3 (Fig. 4c). For M4-M6, the activity increased along with the degree of polymerization (DP) increase and the efficient hydrolytic activity was found on M5 and M6 (Fig. 4c-f). The products mainly were manno-oligosaccharides with DP of $\geq 2$ and only very few mannose was detected. These were similar to the $\beta$-mannanases from $B$. subtilis WL-3 [43], B. subtilis WL-7 [73] and Bacillus sp. AM-001 [74], but different from those from B. subtilis WY34 [67], Bacillus sp. JAMB-602 [9], Enterococcus casseliflavus FL2121 [21], and Pseudomonas sp. strain PT-5 [16] which only hydrolysed manno-oligosaccharides with $\mathrm{DP} \geq 4$. In addition, no products with higher DP than the substrates were found, which indicated that BcManA had no transglycosylation activity. Whereas, some $\beta$-mannanases

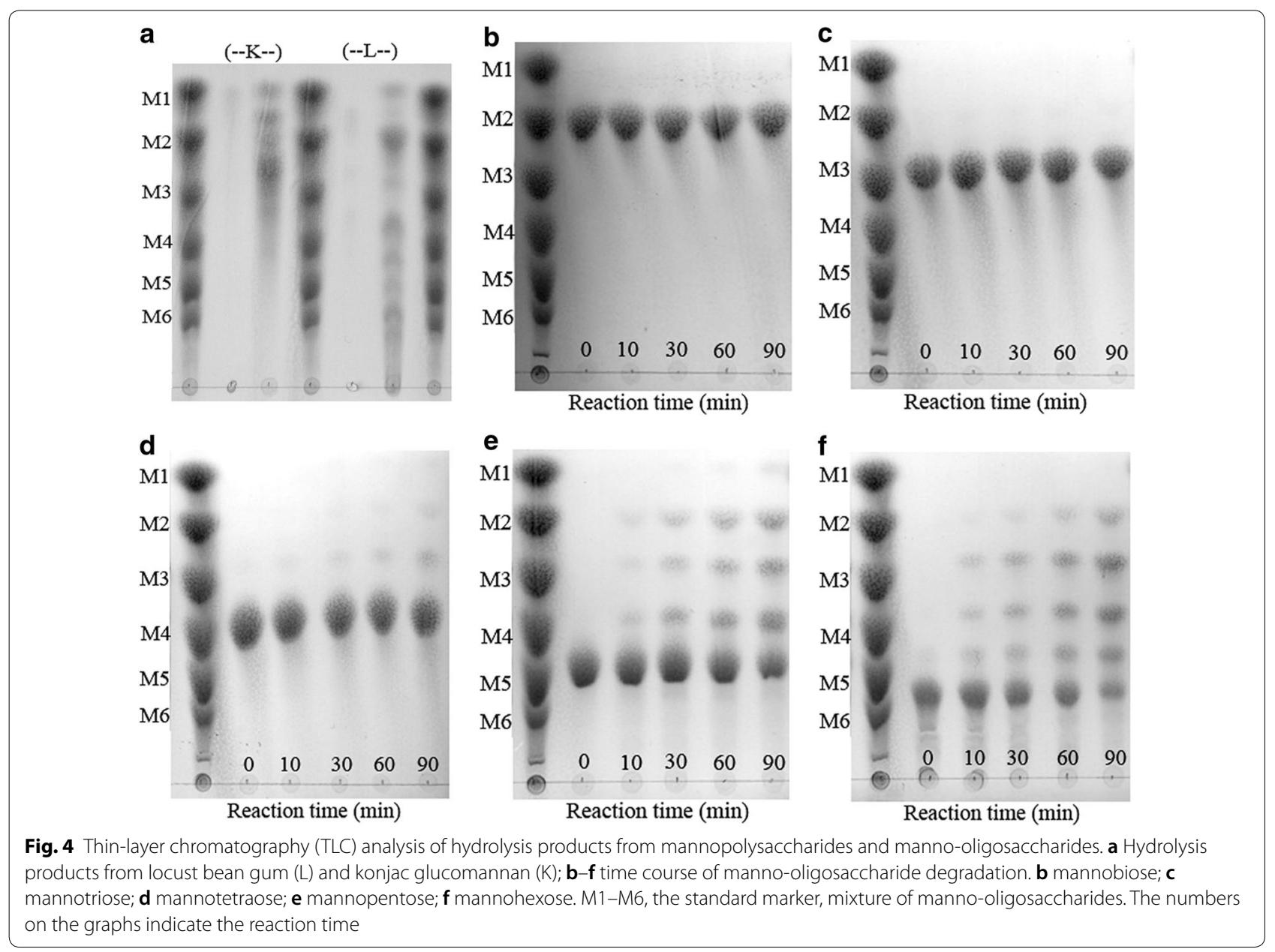


such as that from B. subtilis WL-3 showed transglycosylation activity when manno-oligosaccharides with $\mathrm{DP} \geq 3$ as substrates [43]. Manno-oligosaccharides are generally supplemented in animal feed to improve digestibility and maintain gastrointestinal status, and also used as food additives for humans to promote selective growth of beneficial intestinal microflora [53, 67]. As previous reports, the production of manno-oligosaccharides by acid hydrolysis of mannan is neither environmentally friendly nor cost-effective, whereas the use of alkalithermostable endo mannanase will further improve the yield of manno-oligosaccharides due to high solubility of mannan in alkaline media and reduction in viscosity of the reaction mixture [22]. So BcManA could be a good candidate for manno-oligosaccharides production from cheap mannan such as konjac power and locust bean gum under alkaline and high temperature condition efficiently.

\section{Signal peptides and promoters determination for efficient secreted expression of BcManA in B. subtilis}

Compared to $E$. coli which was extensively used for protein expression, B. subtilis displayed significant advantages in efficient secretion capacity of functional extracellular proteins directly into culture medium, which made downstream separation and purification processes much more simple [5, 44]. In this study, we used the B. subtilis WB600, a protease-deficient strain, for secreted expression of BcManA. The multicopy plasmid pMA5 which containing the constitutive promoter $\mathrm{P}_{\text {hpaII }}$ was used as the expression vector. Firstly, a suitable and efficient signal peptide is necessary for protein secretory expression in B. subtilis [5]. Five different signal peptides $\left(\mathrm{SP}_{\text {lipA }}, \mathrm{SP}_{a m y E}, \mathrm{SP}_{\text {lipB }}, \mathrm{SP}_{a p r E}, \mathrm{SP}_{a m y L}\right)$ from the general secretory $(\mathrm{Sec})$ pathway in $B$. sutilis and the original signal peptide of $\mathrm{BcManA}\left(\mathrm{SP}_{\text {ori }}\right)$ were selected for BcManA secretory expression. After $48 \mathrm{~h}$ cultivation in $2 \times$ SR medium by flask shaking with $1 \%(\mathrm{v} / \mathrm{v})$ inoculation of overnight culture, significant protein bands were found on SDS-PAGE from the culture supernatant (Fig. 5). All the protein banks showed molecular weight about $34 \mathrm{kDa}$ which was in accordance with the calculated molecular weight of the mature BcManA. This indicated that all of the used signal peptides secreted BcManA into the medium successfully. Among these six signal peptides, different level of extracellular activity was detected and the highest activity of $763 \mathrm{U} \mathrm{ml}^{-1}$ was obtained with secretory rate of $95.8 \%$ by B. subtilis WB600-3, which indicated that $\mathrm{SP}_{\text {lipA }}$ was the most efficient signal peptide for BcManA expression in B. subtilis WB600 in this study (Table 5). This was similar to the $\beta$-mannanase from $B$. licheniformis DSM13 which also showed the highest extracellular activity of $533 \mathrm{U} \mathrm{ml}^{-1}$

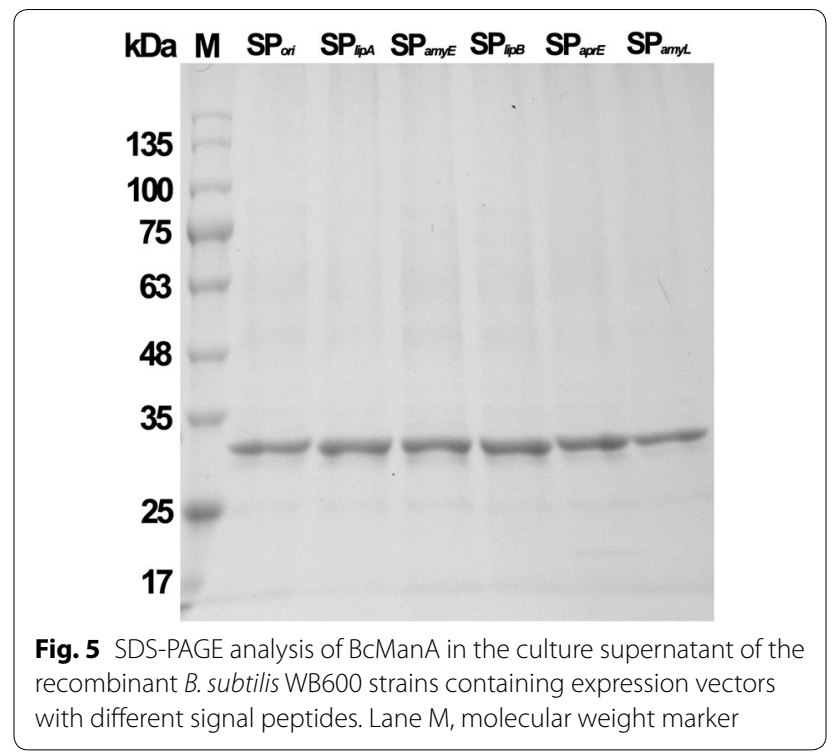

after $72 \mathrm{~h}$ cultivation by $\mathrm{SP}_{l i p A}$ which however, was lower than BcManA [5]. Unexpectedly, B. subtilis WB600-1 containing the expression vector without signal peptide also showed high extracellular activity of $571 \mathrm{U} \mathrm{ml}^{-1}$ after $48 \mathrm{~h}$ cultivation with the secretory rate of $59.6 \%$. We detected the $\beta$-galactosidase activity in the culture supernatant and the whole cell lysate of $B$. subtilis WB600-1, and about $60 \%$ of total $\beta$-galactosidase activity (the activity in the whole cell lysate was set to $100 \%$ ) was found in culture supernatant (data not shown). This result indicated that the high extracellular $\beta$-mannanase activity in B. subtilis WB600-1 culture supernatant might be due to cell lysis after $48 \mathrm{~h}$ cultivation.

Besides the signal peptide, the promoter was another factor for efficient protein expression. So using strong promoters was one of the most efficient methods to increase the proteins production $[5,44]$. The original promoter $\mathrm{P}_{\text {hpaII }}$ in pMA5 was a relatively strong promoter. In order to further increase the expression of BcManA, two other strong promote $\mathrm{P} 43$ and $\mathrm{P}_{\text {laps }}$ were selected. Promoter P43 was a well characterized constitutive strong promoter and widely used in expression of many proteins in B. subtilis $[5,44]$. Whereas, promoter $\mathrm{P}_{\text {laps }}$ was an artificial hybrid promoter containing $\mathrm{P}_{l u x S}$ and the -10 region from $B$. licheniformis and the -35 region of $\mathrm{P}_{A p r}$ from $B$. subtilis, which was confirmed experimentally to be stronger than $\mathrm{P} 43$ for $\beta$-Gal secretory expression in B. subtilis [75]. The strains B. subtilis WB600-8 and $B$. subtilis WB600-9 containing these two strong promoters and $\mathrm{SP}_{l i p A}$ were also cultured in $2 \times \mathrm{SR}$ medium by flask shaking at $37^{\circ} \mathrm{C}$ for $48 \mathrm{~h}$, and the extracellular activity was assayed (Table 5 ). The highest enzyme activity of $908 \mathrm{U} \mathrm{ml}^{-1}$ was produced by B. subtilis WB600-8 
Table 5 Activity of BcManA secreted by different recombinant strains

\begin{tabular}{llll}
\hline Strains & Signal peptide & Promoter & $\begin{array}{l}\text { Activity } \\
\left(\mathbf{U} \mathbf{~ m l}^{-\mathbf{1}} \mathbf{)}\right.\end{array}$ \\
\hline B. subtilis WB600-1 & No SP & $\mathrm{P}_{\text {hpall }}$ & 571 \\
B. subtilis WB600-2 & $\mathrm{SP}_{\text {ori }}$ & $\mathrm{P}_{\text {hpall }}$ & 418 \\
B. subtilis WB600-3 & $\mathrm{SP}_{\text {lipA }}$ & $\mathrm{P}_{\text {hpall }}$ & 763 \\
B. subtilis WB600-4 & $\mathrm{SP}_{\text {amyE }}$ & $\mathrm{P}_{\text {hpall }}$ & 485 \\
B. subtilis WB600-5 & $\mathrm{SP}_{\text {lipB }}$ & $\mathrm{P}_{\text {hpall }}$ & 589 \\
B. subtilis WB600-6 & $\mathrm{SP}_{\text {aprE }}$ & $\mathrm{P}_{\text {hpall }}$ & 448 \\
B. subtilis WB600-7 & $\mathrm{SP}_{\text {amyL }}$ & $\mathrm{P}_{\text {hpall }}$ & 360 \\
B. subtilis WB600-8 & $\mathrm{SP}_{\text {lipA }}$ & $\mathrm{P}_{3}$ & 908 \\
B. subtilis WB600-9 & $\mathrm{SP}_{\text {lipA }}$ & $\mathrm{P}_{\text {lapS }}$ & 122 \\
\hline
\end{tabular}

(P43) which was higher than that produced by B. subtilis WB600-3 $\left(\mathrm{P}_{\text {hpaII }}\right)$. Similar result was also found in the expression of $B$. licheniformis DSM13 $\beta$-mannanase and the activity of $1274 \mathrm{U} \mathrm{ml}^{-1}$ and $711 \mathrm{U} \mathrm{ml}^{-1}$ was produced by $\mathrm{P} 43$ and $\mathrm{P}_{\text {hpaII }}$ after $72 \mathrm{~h}$ cultivation, respectively [5]. The activity of $222 \mathrm{U} \mathrm{ml}^{-1}$ was determined from $B$. subtilis WB600-9 ( $\left.\mathrm{P}_{\text {lapS }}\right)$ which was only about $24.4 \%$ of that from $B$. subtilis WB600-8 (P43). However, for the expression of $\beta$-Gal, the enzyme production driven by $\mathrm{P}_{\text {laps }}$ was more than 10 times of that by $\mathrm{P} 43$ [75]. This indicated that the strongest promoter $\mathrm{P}_{\text {laps }}$ might be not suitable for BcManA expression in B. subtilis WB600. So it shows that promoter with suitable strength is important for protein expression. Further, we determined the cell growth and BcManA production curve of B. subtilis WB600, $B$. subtilis WB600-8 and the original strain B. clausii S10 in different medium (Additional file 1: Fig. S2). No mannanase activity was detected in the B. subtilis WB600 and B. clausii S10 culture supernatant during the entire measuring period. However, small amount of activity was found when B. clausii S10 was cultured in the modified Horikoshi-I medium containing locust bean gum, which indicated that the mannanase production in $B$. clausii $\mathrm{S} 10$ was inducible. The BcManA yield reached to plateau after $72 \mathrm{~h}$ cultivation for both of B. subtilis WB600-8 and $B$. clausii S10. And the extracellular activity from $B$. subtilis WB600-8 reached $2374 \mathrm{U} \mathrm{ml}^{-1}$ with secretory rate of $98.5 \%$ at $72 \mathrm{~h}$, which was much higher than that of native BcManA from B. clausii $\mathrm{S} 10\left(75 \mathrm{U} \mathrm{ml}^{-1}\right)$. Also this enzyme activity was already higher than that produced by other reported B. subtilis strains by shake flask (Table 6) $[5,43,44,76]$.

\section{Optimization for high-level secreted expression of BcManA in B. subtilis}

The medium component was important for industrial enzyme production by microbes. In $2 \times \mathrm{SR}$ medium, yeast extract and tryptone which were expensive and generally used only in laboratory were the carbon and nitrogen source. In order to promote the industrial production performance of the recombinant $B$. subtilis WB600-8 for BcManA, different cheap carbon and nitrogen sources were selected for evaluation. Firstly, peptone, soybean powder, peanut meal and the inorganic nitrogen of $\mathrm{NH}_{4} \mathrm{Cl}$ with $3 \%(\mathrm{w} / \mathrm{v})$ concentration was used to replace tryptone for BcManA expression. As shown in Fig. 6a, obvious extracellular activity was detected after $48 \mathrm{~h}$ cultivation and the highest activity $\left(1050 \mathrm{U} \mathrm{ml}^{-1}\right)$ was found by using peanut meal which was slightly higher than that by using tryptone $\left(908 \mathrm{U} \mathrm{ml}^{-1}\right)$. When the culture time extended to $72 \mathrm{~h}$, a higher activity using peanut meal reached $2645 \mathrm{U} \mathrm{ml}^{-1}$ compared with $2374 \mathrm{U} \mathrm{ml}^{-1}$ using tryptone. Peanut meals are cheap and abundant byproducts of oil extraction from peanut seeds. So they can be used as cheap nitrogen source for $\beta$-mannanase production by recombinant $B$. subtilis.

Using peanut meal as nitrogen source, different carbon source such as glucose, glycine, corn starch, soluble starch, konjac flour and dextrin with $2 \%(\mathrm{w} / \mathrm{v})$ concentration were used instead of yeast extract for BcManA expression. After $48 \mathrm{~h}$ cultivation, the highest activity of only $69 \mathrm{U} \mathrm{ml}^{-1}$ was determined using glucose as carbon source among these modified mediums, which was at very low level compared with that using yeast extract. These results indicated that yeast extract might be important for BcManA production in B. subtilis. On the other hand, we found that the cell concentration in the glucose medium was observably higher than that in the yeast extract medium, along with $\mathrm{pH}$ decrease. This phenomenon indicated that glucose in medium could improve $B$. subtilis cells growth to high biomass, however, which resulted in more acid by-products and low level of protein expression. Nevertheless, yeast extract should be partially substituted by cheap carbon source such as glucose to balance the protein expression and cell growth. Different proportions substitution of yeast extract by glucose was performed with the total concentration of $5 \%(\mathrm{w} / \mathrm{v})$. As shown in Fig. 6b, the highest activity of $3804 \mathrm{U} \mathrm{ml}^{-1}$ was found after $72 \mathrm{~h}$ cultivation in the medium containing $3 \%$ yeast extract and $2 \%$ glucose, which was about 2.5 times as much as that only using $5 \%$ yeast extract. Further, the effect of peanut meal concentration on BcManA expression was also evaluated. As shown in Fig. 6c, the highest yield of $4599 \mathrm{U} \mathrm{ml}^{-1}$ was obtained after $72 \mathrm{~h}$ when $5 \%$ peanut meal was used in the modified medium. In addition, the inoculation amount is also an important fact for protein expression. The extracellular enzyme yield under different inoculation amount was detected using the optimally modified $2 \times$ SR medium (5\% peanut meal, $3 \%$ yeast extract, $2 \%$ glucose, $0.6 \% \mathrm{~K}_{2} \mathrm{HPO}_{4}, \mathrm{pH} 7.2$ ). Finally, 
Table 6 Secreted production of recombinant $\beta$-mannanases in different strains by shake flask

\begin{tabular}{|c|c|c|c|c|c|c|c|}
\hline Gene source & Expression hosts & Expression vector & $\begin{array}{l}\text { Culture } \\
\text { time (h) }\end{array}$ & Activity $\left(\mathrm{U} \mathrm{ml}^{-1}\right)$ & $\begin{array}{l}\text { Productivity } \\
\left(\mathrm{U} \mathrm{ml}^{-1} \mathrm{~h}^{-1}\right)\end{array}$ & $\begin{array}{l}\text { Enzyme pH } \\
\text { optima }\end{array}$ & References \\
\hline B. clausii S10 & B. subtilis WB600 & pMA5 & 72 & 6041 & 83.9 & 9.5 & This work \\
\hline B. licheniformis DSM13 & B. subtilis 1A751 & pMA5 & 72 & 2207 & 30.7 & 5.5 & {$[5]$} \\
\hline B. subtilis WL-3 & B. subtilis 168 & $\mathrm{pJ} 2788 \mathrm{U}$ & 15 & 450 & 30.0 & 6.0 & [43] \\
\hline B. pumilus Nsic-2 & B. subtilis 1A751 & pBNS2 & 24 & 7 & 0.3 & 7.0 & [44] \\
\hline B. subtilis BCC41051 & B. megaterium & $\mathrm{pXb}$ & 24 & 359 & 15.0 & 7.0 & {$[76]$} \\
\hline Bispora sp. MEY-1 & P. pastoris GS115 & pPIC9 & 48 & 64 & 1.3 & $1.0-1.5$ & [59] \\
\hline A. fumigatus & P. pastoris GS115 & pPICZaC & 10 & 61 & 6.1 & 5.2 & [26] \\
\hline A. niger BK01 & P. pastoris X33 & $\mathrm{pPICZaA}$ & 96 & 669 & 7.0 & 4.5 & {$[27]$} \\
\hline B. subtilis MAFIC-S11 & P. pastoris X33 & pPICZaA & 72 & 1106 & 15.4 & 6.0 & {$[42]$} \\
\hline A. sulphureus & P. pastoris X33 & $\mathrm{pPICZaA}$ & 96 & 96 & 1.0 & 2.4 & {$[28]$} \\
\hline B. subtilis G1 & P. pastoris GS115 & pPICZaA & 108 & 224 & 2.1 & 6.5 & {$[80]$} \\
\hline A. niger CBS 513.88 & P. pastoris GS115 & pHBM905M & 192 & 274 & 1.4 & 4.5 & {$[61]$} \\
\hline B. subtilis BS5 & P. pastoris GS115 & pPIC9 & 96 & 892 & 9.3 & 6.0 & [41] \\
\hline Bacillus sp. N16-5 & P. pastoris GS115 & pPIC9K & 144 & 1114 & 7.7 & 9.0 & {$[45]$} \\
\hline Penicillium sp. C6 & P. pastoris GS115 & pPIC9 & 120 & 566 & 4.7 & 4.5 & {$[66]$} \\
\hline Bacillus sp. N16-5 & P. pastoris GS115 & pPICZaA & 120 & 32 & 0.3 & 10.0 & [40] \\
\hline Penicillium oxalicum & P. pastoris GS115 & pPICZaA & 144 & 84 & 0.6 & 4.0 & {$[30]$} \\
\hline B. circulans NT 6.7 & E. coli BL21 (DE3) & pET21d & 16 & 37 & 2.3 & 6.0 & [38] \\
\hline B. licheniformis DSM13 & E. coliTop10 & pFLAG-CTS & $4^{\mathrm{a}}$ & 13 & 3.4 & $6.0-7.0$ & {$[37]$} \\
\hline Bacillus sp. N16-5 & E. coli BL21 (DE3) & pET22b & 28 & 2736 & 97.7 & 9.0 & [39] \\
\hline A. aculeatus MRC11624 & A. niger D15 & pGT & 192 & $16,596^{b}$ & 35.4 & 3.8 & [77] \\
\hline A. fumigatus & A. sojae & pAN52-4 & 144 & 352 & 2.4 & 4.5 & [26] \\
\hline A. niger CBS 513.88 & Y. lipolytica & pINA1296I & 48 & 255 & 5.3 & 4.5 & {$[78]$} \\
\hline B. licheniformis DSM13 & L.plantarum & pSIP609 & 12 & 42 & 3.5 & 6.0 & [79] \\
\hline T. harzianum MGQ2 & T. reesei OM9414 & pUC19 & 168 & 2460 & 14.6 & 6.0 & {$[31]$} \\
\hline
\end{tabular}

a The time is the induction time

b The activity defined as the amount of enzyme required to convert one mole of substrate per second and reported in katal ( $\mathrm{nkat} \mathrm{ml}^{-1}$ )

the highest activity was determined to be $6041 \mathrm{U} \mathrm{ml}^{-1}$ after $72 \mathrm{~h}$ cultivation when the inoculum size of $6 \%(\mathrm{v} / \mathrm{v})$ was used (Fig. 6d), which was about 80 times that of native BcManA from B. clausii S10.

In the past decade, many strains such as Bacillus sp., $P$. pastoris, E. coli, Aspergillus sp. and some least frequently used strains have been applied for $\beta$-mannanases production (Table 6). Among these reports, B. subtilis and $P$. pastoris are the most commonly used host strains for $\beta$-mannanases expression, and most of the $\beta$-mannanases had neutral or acid optimal pH. Song et al. reported the secreted expression of $\beta$-mannanase from $B$. licheniformis DSM13 in B. subtilis 1A751 through protein synthesis and secretion optimization strategy, and they improved the final production to $2207 \mathrm{U} \mathrm{ml}^{-1}$ by shake flask which was considered to be the highest among the reported Bacillsu strains [5]. Our result showed a yield of $6041 \mathrm{U} \mathrm{ml}^{-1}$ which was about 2.7 times as much as that expressed in B. subtilis 1A751, which indicating the highest $\beta$-mannanase yield produced by Bacillus strains by shake flask. Compared to Bacillus, much more secreted expression of $\beta$-mannanase was performed in P. pastoris strains (Table 6). The highest yield by shake flask was $1114 \mathrm{U} \mathrm{ml}^{-1}$ with productivity of only $7.7 \mathrm{U} \mathrm{ml}^{-1} \mathrm{~h}^{-1}$ after 144 h cultivation in P. pastoris GS115 using PPIC9K vector [55]. Besides these commonly used strains, some other host strains such as A. niger [77], A. sojae [26], Yarrowia lipolytica [78], Lactobacillus plantarum [79] and Trichoderma reesei [31] were also used for $\beta$-mannanases production. The extracellular activity of $\beta$-mannanase from A. aculeatus MRC11624 was found to be 16,596 nkat $\mathrm{ml}^{-1}$ (about $996 \mathrm{U} \mathrm{ml}^{-1}$ ) after $192 \mathrm{~h}$ cultivation in $A$. niger D15 [77]. Higher activity of $2460 \mathrm{U} \mathrm{ml}^{-1}$ with productivity of $14.6 \mathrm{U} \mathrm{ml}^{-1} \mathrm{~h}^{-1}$ was obtained for ThMan5 after $72 \mathrm{~h}$ cultivation in T. reesei QM9414A [31]. In the present study, combined with selection of suitable signal peptide for efficient secretory, strong promoters to enhance the transcription and translation, and optimization of medium for strain growth and protein expression, the extracellular activity of BcManA reached $6041 \mathrm{U} \mathrm{ml}^{-1}$ with productivity of $83.9 \mathrm{U} \mathrm{ml}^{-1} \mathrm{~h}^{-1}$ after $72 \mathrm{~h}$ cultivation by flask shake, which was higher than those of not only 

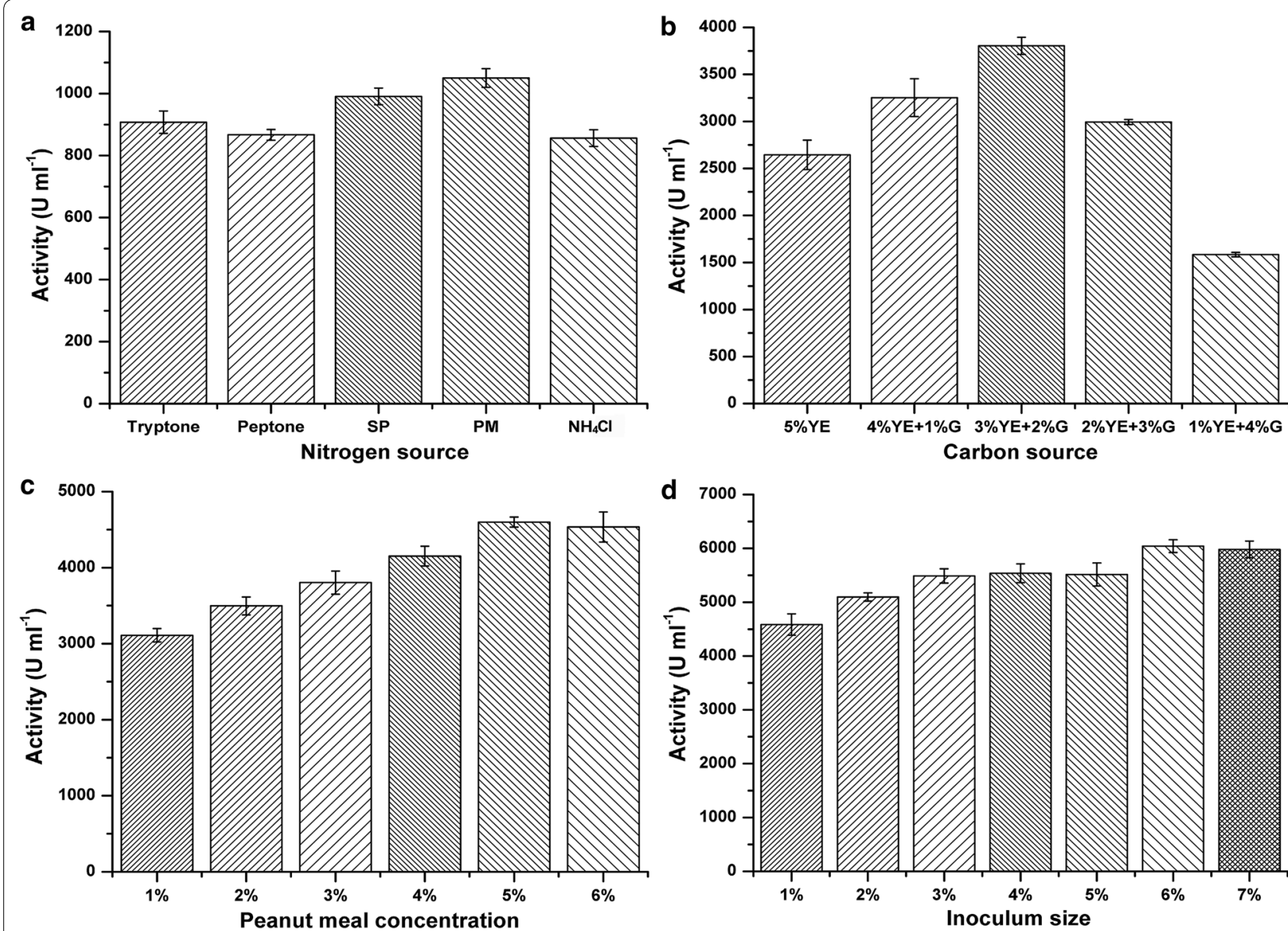

Fig. 6 Extracellular $\beta$-mannanase activity of the recombinant B. subtilis WB600-8 cultured in $50 \mathrm{ml}$ of various modified $2 \times \mathrm{SR}$ mediums. a Different nitrogen sources with $3 \%$ concentration in $2 \times$ SR medium; $\mathbf{b}$ different proportions substitution of yeast extract (YE) by glucose (G) in the modified $2 \times$ SR medium with $3 \%$ peanut meal as nitrogen source; $\mathbf{c}$ different peanut concentration in the modified $2 \times$ SR medium with $3 \%$ yeast extract and $2 \%$ glucose; $\mathbf{d}$ different doses of inoculation in the final modified medium containing $5 \%$ peanut meal, $3 \%$ yeast extract, $2 \%$ glucose and $0.6 \%$ $\mathrm{K}_{2} \mathrm{HPO}_{4}$. Error bars represent standard deviations

Bacillus strains but also all other reported strains by flask shake fermentation. Also the modified $2 \times \mathrm{SR}$ medium was cheaper than the normally used $2 \times$ SR medium and could be applied for other protein expression in B. subtilis. Moreover, a much higher production of BcManA would be obtained by cultivating this strain in fed-batch fermentors with process optimization.

\section{Conclusions}

The thermo-alkaline $\beta$-mannanase (BcManA) gene from $B$. clausii was cloned and heterologous expressed. The purified recombinant BcManA showed high catalytic activity on konjac glucomannan and locust bean gum under alkaline and high temperature conditions. Overall consideration of $\mathrm{pH}$ and temperature performance, BcManA distinguished from other reported $\beta$-mannanases and was a promising thermo-alkaline $\beta$-mannanase for potential industrial application. Combined with medium optimization and selection of suitable signal peptide and strong promoters, the extracellular BcManA yield of $6041 \mathrm{U} \mathrm{ml}^{-1}$ was obtained in B. subtilis WB600 with constitutive expression vector, which representing the highest yield reported to date by flask shake. This would significantly cut down the production cost of this enzyme and provide a guideline for secretory expression of other $\beta$-mannanases in B. subtilis. 


\section{Additional files}

Additional file 1: Table S1. Primers for expression plasmid construction with different signal peptides by modified Gibson method. Table S2. Primers for expression plasmid construction with different promoters by modified Gibson method.

Additional file 2: Fig. S1. The screening result of the positive mannanase clone on the LB agar plate containing locust bean gum. The colony pointed out by white arrow showed transparent zone which indicated positive mannanase activity. Fig. S2. Time profiles for mannanase activity by B. clausii S10, B. subtilis WB600 and the recombinant B. subtilis WB600-8. Black square-extracellular activity by B. subtilis WB600-8 in $2 \times$ SR medium; black circle-extracellular activity by B. clausii S10 in modified Horikoshi-I medium containing konjac glucomannan; white square-the $\mathrm{OD}_{600}$ value of B. subtilis WB600-8; white circle-the $\mathrm{OD}_{600}$ value of $B$. clausii $\mathrm{S} 10$ in modified Horikoshi-I medium containing konjac glucomannan; white triangle-the $\mathrm{OD}_{600}$ value of B. clausii S10 in Horikoshi-I medium; white inverted trianglethe $\mathrm{OD}_{600}$ value of $B$. subtilis WB600 in $2 \times \mathrm{SR}$ medium. Due to no activity was detected in the entire measuring period, the enzyme production curves of B. subtilis WB600 and B. clausii S10 in Horikoshi-I medium were not shown on this figure.

\section{Authors' contributions}

CZ designed and performed the experiments and wrote the manuscript. YFX participated in drafting the manuscript. YHM conceived the initial idea and supervised the whole work. All authors read and approved the final manuscript.

\section{Author details}

1 State Key Laboratory of Microbial Resources, Institute of Microbiology, Chinese Academy of Sciences, Beijing 100101, China. ${ }^{2}$ National Engineering Laboratory for Industrial Enzymes, Institute of Microbiology, Chinese Academy of Sciences, Beijing 100101, China.

\section{Acknowledgements}

Not applicable.

\section{Competing interests}

The authors declare that they have no competing interests.

\section{Availability of data and materials}

The datasets supporting the conclusions of this article are included in the manuscript and additional files.

\section{Consent for publication}

Not applicable.

\section{Ethics approval and consent to participate}

Not applicable.

\section{Funding}

This work was supported by the Key Research Program of the Chinese Academy of Sciences (KFZD-SW-201-2) and the National Basic Research Program of China (2013CBA733900).

\section{Publisher's Note}

Springer Nature remains neutral with regard to jurisdictional claims in published maps and institutional affiliations.

Received: 3 May 2018 Accepted: 3 August 2018 Published online: 11 August 2018

\section{References}

1. Chauhan PS, Puri N, Sharma P, Gupta N. Mannanases: microbial sources, production, properties and potential biotechnological applications. Appl Microbiol Biotechnol. 2012;93(5):1817-30.
2. Srivastava PK, Kapoor M. Production, properties, and applications of endo-ß-mannanases. Biotechnol Adv. 2017;35(1):1-19.

3. Filichkin SA, Leonard JM, Monteros A, Liu PP, Nonogaki H. A novel endo-beta-mannanase gene in tomato LeMAN5 is associated with anther and pollen development. Plant Physiol. 2004;134(3):1080-7.

4. Xu B, Hägglund P, Stålbrand H, Janson JC. Endo-beta-1,4-mannanases from blue mussel, Mytilus edulis: purification, characterization, and mode of action. J Biotechnol. 2002;92(3):267-77.

5. Song Y, Fu G, Dong H, Li J, Du Y, Zhang D. High-efficiency secretion of $\beta$-Mannanase in Bacillus subtilis through protein synthesis and secretion optimization. J Agric Food Chem. 2017;65(12):2540-8.

6. Talbot G, Sygusch J. Purification and characterization of thermostable beta-mannanase and alpha-galactosidase from Bacillus stearothermophilus. Appl Environ Microbiol. 1990;56(11):3505-10.

7. Ooi T, Kikuchi D. Purification and some properties of $\beta$-mannanase from Bacillus sp. World J Microbiol Biotechnol. 1995;11(3):310-4.

8. Zhang J, He ZM, Hu K. Purification and characterization of $\beta$-mannanase from Bacillus licheniformis for industrial use. Biotechnol Lett. 2000;22:1375-8.

9. Takeda N, Hirasawa K, Uchimura K, Nogi Y, Hatada Y, Akita M, Usami R, Yoshida Y, Grant WD, Ito S, Horikoshi K. Alkaline mannanase from a novel species of alkaliphilic Bacillus. J Appl Glycosci. 2004;51:229-36.

10. Ma Y, Xue Y, Dou Y, Xu Z, Tao W, Zhou P. Characterization and gene cloning of a novel beta-mannanase from alkaliphilic Bacillus sp. N16-5. Extremophiles. 2004;8(6):447-54.

11. Li YN, Meng K, Wang YR, Yao B. A beta-mannanase from Bacillus subtilis B36: purification, properties, sequencing, gene cloning and expression in Escherichia coli. Z Naturforsch C. 2006;61(11-12):840-6.

12. Li Y, Yang P, Meng K, Wang Y, Luo H, Wu N, Fan Y, Yao B. Gene cloning, expression, and characterization of a novel $\beta$-mannanase from Bacillus circulans CGMCC 1416. J Microbiol Biotechnol. 2008;18(1):160-6.

13. Chauhan PS, Sharma P, Puri N, Gupta N. Purification and characterization of an alkali-thermostable $\beta$-mannanase from Bacillus nealsonii PN-11 and its application in manno-oligosaccharides preparation having prebiotic potential. Eur Food Res Technol. 2014;238:927-36.

14. Zang H, Xie S, Wu H, Wang W, Shao X, Wu L, Rajer FU, Gao X. A novel thermostable GH5_7 $\beta$-mannanase from Bacillus pumilus GBSW19 and its application in manno-oligosaccharides (MOS) production. Enzyme Microb Technol. 2015;78:1-9.

15. Nakajima N, Matsuura Y. Purification and characterization of konjac glucomannan degrading enzyme from anaerobic human intestinal bacterium, Clostridium butyricum-Clostridium beijerinckii group. Biosci Biotechnol Biochem. 1997;61(10):1739-42.

16. Yamaura L, Matsumoto T, Funatsu M, Funatsu Y. Purification and some properties of endo-1,4- $\beta$-D-mannanase from Pseudomonas sp. PT-5. Agric Biol Chem. 1990;54:2425-7.

17. Tamaku Y, Akaki T, Morishita T, Kimura T, Sakka K, Ohmiya K. Cloning, DNA sequencing, and expression of the $\beta$-1,4-mannanase gene from a marine bacterium, Vibrio sp. strain MA-138. J Ferment Bioeng. 1997;83:201-5.

18. Parker KN, Chhabra SR, Lam D, Callen W, Duffaud GD, Snead MA, Short IM, Mathur EJ, Kelly RM. Galactomannanases Man2 and Man5 from Thermotoga species: growth physiology on galactomannans, gene sequence analysis, and biochemical properties of recombinant enzymes. Biotechnol Bioeng. 2001;75(3):322-33.

19. Politz O, Krah M, Thomsen KK, Borriss R. A highly thermostable endo$(1,4)$-beta-mannanase from the marine bacterium Rhodothermus marinus. Appl Microbiol Biotechnol. 2000;53(6):715-21.

20. Titapoka S, Keawsompong S, Haltrich D, Nitisinprasert S. Selection and characterization of mannanase producing bacteria useful for the formation of pre biotic manno oligosaccharides from copra meal. World J Microbiol Biotechnol. 2008;24:1425-33.

21. Oda Y, Komaki T, Tonomura K. Purification and properties of extracellular $\beta$-mannanases produced by Enterococcus casseliflavus FL2121 isolated from decayed Konjac. J Ferment Bioeng. 1993:76:14-8.

22. Pradeep GC, Cho SS, Choi YH, Choi YS, Jee JP, Seong CN, Yoo JC. An extremely alkaline mannanase from Streptomyces sp. CS428 hydrolyzes galactomannan producing series of mannooligosaccharides. World J Microbiol Biotechnol. 2016;32(5):84

23. Stoll D, Stålbrand H, Warren RA. Mannan-degrading enzymes from Cellulomonas fimi. Appl Environ Microbiol. 1999;65(6):2598-605. 
24. Chen CY, Huang YC, Yang TY, Jian JY, Chen WL, Yang CH. Degradation of konjac glucomannan by Thermobifida fusca thermostable $\beta$-mannanase from yeast transformant. Int J Biol Macromol. 2016;82:1-6.

25. Lu H, Luo H, Shi P, Huang H, Meng K, Yang P, Yao B. A novel thermophilic endo- $\beta$-1,4-mannanase from Aspergillus nidulans XZ3: functional roles of carbohydrate-binding module and Thr/Ser-rich linker region. Appl Microbiol Biotechnol. 2014;98(5):2155-63.

26. Duruksu G, Ozturk B, Biely P, Bakir U, Ogel ZB. Cloning, expression and characterization of endo-beta-1,4-mannanase from Aspergillus fumigatus in Aspergillus sojae and Pichia pastoris. Biotechnol Prog. 2009;25(1):271-6.

27. Do BC, Dang TT, Berrin JG, Haltrich D, To KA, Sigoillot JC, Yamabhai M. Cloning, expression in Pichia pastoris, and characterization of a thermostable GH5 mannan endo-1,4-beta-mannosidase from Aspergillus niger BK01. Microb Cell Fact. 2009;8:59.

28. Chen $X, C a o$ Y, Ding Y, Lu W, Li D. Cloning, functional expression and characterization of Aspergillus sulphureus beta-mannanase in Pichia pastoris. J Biotechnol. 2007;128(3):452-61.

29. Li JF, Zhao SG, Tang CD, Wang JQ, Wu MC. Cloning and functional expression of an acidophilic $\beta$-mannanase gene (Anman5A) from Aspergillus niger LW-1 in Pichia pastoris. J Agric Food Chem. 2012;60(3):765-73.

30. Liao H, Li S, Zheng H, Wei Z, Liu D, Raza W, Shen Q, Xu Y. A new acidophilic thermostable endo-1,4- $\beta$-mannanase from Penicillium oxalicum GZ-2: cloning, characterization and functional expression in Pichia pastoris. BMC Biotechnol. 2014;14:90.

31. Wang J, Zeng D, Liu G, Wang S, Yu S. Truncation of a mannanase from Trichoderma harzianum improves its enzymatic properties and expression efficiency in Trichoderma reesei. J Ind Microbiol Biotechnol. 2014;41(1):125-33.

32. Yang $H$, Shi $P$, Lu H, Wang H, Luo H, Huang H, Yang P, Yao B. A thermophilic $\beta$-mannanase from Neosartorya fischeri P1 with broad pH stability and significant hydrolysis ability of various mannan polymers. Food Chem 2015:173:283-9.

33. Zhu T, You L, Gong F, Xie M, Xue Y, Li Y, Ma Y. Combinatorial strategy of sorbitol feeding and low-temperature induction leads to high-level production of alkaline $\beta$-mannanase in Pichia pastoris. Enzyme Microb Technol. 2011:49(4):407-12.

34. Sunna A, Gibbs MD, Chin CW, Nelson PJ, Bergquist PL. A gene encoding a novel multidomain $\beta$-1,4-mannanase from Caldibacillus cellulovorans and action of the recombinant enzyme on kraft pulp. Appl Environ Microbiol. 2000;66(2):664-70.

35. David A, Singh Chauhan P, Kumar A, Angural S, Kumar D, Puri N, Gupta N. Coproduction of protease and mannanase from Bacillus nealsonii PN-11 in solid state fermentation and their combined application as detergent additives. Int J Biol Macromol. 2018;108:1176-84.

36. Hu K, Li CX, Pan J, Ni Y, Zhang XY, Xu JH. Performance of a new thermostable mannanase in breaking guar-based fracturing fluids at high temperatures with little premature degradation. Appl Biochem Biotechnol. 2014;172(3):1215-26.

37. Songsiriritthigul C, Buranabanyat B, Haltrich D, Yamabhai M. Efficient recombinant expression and secretion of a thermostable GH26 mannan endo-1,4-beta-mannosidase from Bacillus licheniformis in Escherichia coli. Microb Cell Fact. 2010;9:20.

38. Piwpankaew Y, Sakulsiriat $\mathrm{S}$, Nitisinprasert $\mathrm{S}$, Nguyen TH, Haltrich D, Keawsompong S. Cloning, secretory expression and characterization of recombinant $\beta$-mannanase from Bacillus circulans NT 6.7. Springerplus. 2014;3:430.

39. Zheng H, Yu Z, Fu X, Li S, Xu J, Song H, Ma Y. High level extracellular production of a truncated alkaline $\beta$-mannanase from alkaliphilic Bacillus $\mathrm{sp}$. N16-5 in Escherichia coli by the optimization of induction condition and fed-batch fermentation. J Ind Microbiol Biotechnol. 2016:43(7):977-87.

40. He X, Liu N, Li W, Zhang Z, Zhang B, Ma Y. Inducible and constitutive expression of a novel thermostable alkaline $\beta$-mannanase from alkaliphilic Bacillus sp. N16-5 in Pichia pastoris and characterization of the recombinant enzyme. Enzyme Microb Technol. 2008:43:13-8.

41. Li RK, Chen P, Ng TB, Yang J, Lin J, Yan F, Ye XY. Highly efficient expression and characterization of a $\beta$-mannanase from Bacillus subtilis in Pichia pastoris. Biotechnol Appl Biochem. 2015;62(1):64-70.

42. LV J, Chen Y, Pei H, Yang W, Li Z, Dong B, Cao Y. Cloning, expression, and characterization of $\beta$-mannanase from Bacillus subtilis MAFIC-S11 in Pichia pastoris. Appl Biochem Biotechnol. 2013;169(8):2326-40.
43. Yoon KH, Lim BL. Cloning and strong expression of a Bacillus subtilis WL-3 mannanase gene in B. subtilis. J Microbiol Biotechnol. 2007:17(10):1688-94.

44. Guo S, Tang JJ, Wei DZ, Wei W. Construction of a shuttle vector for protein secretory expression in Bacillus subtilis and the application of the mannanase functional heterologous expression. J Microbiol Biotechnol. 2014;24(4):431-9.

45. Pan X, Zhou J, Tian A, Le K, Yuan H, Xue Y, Ma Y, Lu H. High level expression of a truncated $\beta$-mannanase from alkaliphilic Bacillus sp. N16-5 in Kluyveromyces cicerisporus. Biotechnol Lett. 2011;33(3):565-70.

46. Gibson DG, Young L, Chuang RY, Venter JC, Hutchison CA, Smith HO. Enzymatic assembly of DNA molecules up to several hundred kilobases. Nat Methods. 2009;6(5):343-5.

47. Yang MM, Zhang WW, Bai XT, Li HX, Cen PL. Electroporation is a feasible method to introduce circularized or linearized DNA into B. subtilis chromosome. Mol Biol Rep. 2010;37(5):2207-13.

48. Zhao Y, Zhang Y, Cao Y, Qi J, Mao L, Xue Y, Gao F, Peng H, Wang X, Gao GF, Ma Y. Structural analysis of alkaline $\beta$-mannanase from alkaliphilic Bacillus sp. N16-5: implications for adaptation to alkaline conditions. PLOS ONE. 2011:6(1):e14608.

49. Vijayalaxmi S, Prakash P, Jayalakshmi SK, Mulimani VH, Sreeramulu K. Production of extremely alkaliphilic, halotolerent, detergent, and thermostable mannanase by the free and immobilized cells of Bacillus halodurans PPKS-2. Purification and characterization. Appl Biochem Biotechnol. 2013;171(2):382-95.

50. Hatada Y, Takeda N, Hirasawa K, Ohta Y, Usami R, Yoshida Y, Grant WD, Ito $\mathrm{S}$, Horikoshi K. Sequence of the gene for a high-alkaline mannanase from an alkaliphilic Bacillus sp. strain JAMB-750, its expression in Bacillus subtilis and characterization of the recombinant enzyme. Extremophiles. 2005;9(6):497-500.

51. Yang $P, L i Y$, Wang Y, Meng K, Luo H, Yuan T, Bai Y, Zhan Z, Yao B. A novel beta-mannanase with high specific activity from Bacillus circulans CGMCC1554: gene cloning, expression and enzymatic characterization. Appl Biochem Biotechnol. 2009;159(1):85-94.

52. Yoshida S, Sako Y, Uchida A. Cloning, sequence analysis, and expression in Escherichia coli of a gene coding for an enzyme from Bacillus circulans K-1 that degrades guar gum. Biosci Biotechnol Biochem. 1998;62(3):514-20.

53. Regmi S, Yoo HY, Choi YH, Choi YS, Yoo JC, Kim SW. Prospects for bioindustrial application of an extremely alkaline mannanase from Bacillus subtilis subsp. inaquosorum CSB31. Biotechnol J. 2017;12(11):1700113.

54. El-Sharouny EE, El-Toukhy NM, El-Sersy NA, El-Gayar AA. Optimization and purification of mannanase produced by an alkaliphilic-thermotolerant Bacillus cereus N1 isolated from Bani Salama Lake in Wadi El-Natron. Biotechnol Biotechnol Equip. 2015;29(2):315-23.

55. Zhang M, Chen XL, Zhang ZH, Sun CY, Chen LL, He HL, Zhou BC, Zhang $Y Z$. Purification and functional characterization of endo-beta-mannanase MAN5 and its application in oligosaccharide production from konjac flour. Appl Microbiol Biotechnol. 2009;83(5):865-73.

56. Mendoza NS, Arai M, Kawaguchi T, Yoshida T, Joson LM. Purification and properties of mannanase from Bacillus subtilis. World J Microbiol Biotechnol. 1994;10(5):551-5.

57. Wang C, Zhang J, Wang Y, Niu C, Ma R, Wang Y, Luo H, Yao B. Biochemical characterization of an acidophilic $\beta$-mannanase from Gloeophyllum trabeum CBS900.73 with significant transglycosylation activity and feed digesting ability. Food Chem. 2016;197(Pt A):474-81.

58. Zhao J, Shi P, Luo H, Yang P, Zhao H, Bai Y, Huang H, Wang H, Yao B. An acidophilic and acid-stable beta-mannanase from Phialophora sp. p13 with high mannan hydrolysis activity under simulated gastric conditions. J Agric Food Chem. 2010;58(5):3184-90.

59. Luo $H$, Wang $Y$, Wang $H$, Yang J, Yang $Y$, Huang $H$, Yang $P$, Bai $Y$, Shi $P$, Fan $Y$, Yan B. A novel highly acidic beta-mannanase from the acidophilic fungus Bispora sp. MEY-1: gene cloning and overexpression in Pichia pastoris. Appl Microbiol Biotechnol. 2009:82(3):453-61.

60. Luo Z, Miao J, Li G, Du Y, Yu X. A recombinant highly thermostable B-mannanase (ReTMan26) from thermophilic Bacillus subtilis (TBS2) expressed in Pichia pastoris and its $\mathrm{pH}$ and temperature stability. Appl Biochem Biotechnol. 2017;182(4):1259-75.

61. Yu S, Li Z, Wang Y, Chen W, Fu L, Tang W, Chen C, Liu Y, Zhang X, Ma L. High-level expression and characterization of a thermophilic 
$\beta$-mannanase from Aspergillus niger in Pichia pastoris. Biotechnol Lett. 2015;37(9):1853-9.

62. Cheng L, Duan S, Feng X, Zheng K, Yang Q, Liu Z. Purification and characterization of a thermostable $\beta$-mannanase from Bacillus subtilis BE-91: potential application in inflammatory diseases. Biomed Res Int 2016;2016:6380147.

63. Seesom W, Thongket P, Yamamoto T, Takenaka S, Sakamoto T, Sukhumsirichart W. Purification, characterization, and overexpression of an endo-1,4- $\beta$-mannanase from thermotolerant Bacillus sp. SWU60. World J Microbiol Biotechnol. 2017;33(3):53.

64. Hakamada Y, Ohkubo Y, Ohashi S. Purification and characterization of $\beta$-mannanase from Reinekea sp. KIT-YO10 with transglycosylation activity. Biosci Biotechnol Biochem. 2014;78(4):722-8.

65. Mou H, Zhou F, Jiang X, Liu Z. Production, purification and properties of $\beta$-mannanase from soil bacterium Bacillus circulans M-21. J Food Biochem. 2011;35:1451-60.

66. Cai H, Shi P, Luo H, Bai Y, Huang H, Yang P, Yao B. Acidic $\beta$-mannanase from Penicillium pinophilum $\mathrm{C}$ : cloning, characterization and assessment of its potential for animal feed application. J Biosci Bioeng. 2011;112(6):551-7.

67. Jiang ZJ, Wei Y, Li DY, Li L, Chai PP, Kusakabe I. High-level production, purification and characterization of a thermostable $\beta$-mannanase from the newly isolated Bacillus subtilis WY34. Carbohydr Polym. 2006;66:88-96.

68. Regmi S, Pradeep GC, Choi YH, Choi YS, Choi JE, Cho SS, Yoo JC. A multitolerant low molecular weight mannanase from Bacillus sp. CSB39 and its compatibility as an industrial biocatalyst. Enzyme Microb Technol. 2016;92:76-85.

69. Singh G, Bhalla A, Hoondal GS. Solid state fermentation and characterization of partially purified thermostable mannanase from Bacillus sp. MG-33. BioResources. 2010;5(3):1689-701.

70. Zhang R, Song Z, Wu Q, Zhou J, Li J, Mu Y, Tang X, Xu B, Ding J, Deng S, Huang Z. A novel surfactant-, $\mathrm{NaCl}$-, and protease-tolerant $\beta$-mannanase from Bacillus sp. HJ14. Folia Microbiol (Praha). 2016;61 (3):233-42.
71. Liu HX, Gong JS, Li H, Lu ZM, Li H, Qian JY, Xu ZH, Shi JS. Biochemical characterization and cloning of an endo-1,4-mannanase from Bacillus subtilis YH12 with unusually broad substrate profile. Process Biochem. 2015;50:712-21.

72. Khanongnuch C, Asada K, Tsuruga H, Ooi T, Kinoshita S, Lumyong S. $\beta$-Mannanase and xylanase of Bacillus subtilis $5 \mathrm{H}$ active for bleaching of crude pulp. J Ferment Bioeng. 1998;86:461-6.

73. Kweun MA, Lee MS, Choi JH, Cho KH, Yoon KH. Cloning of a Bacillus subtilis WL-7 mannanase gene and characterization of the gene product. J Microbiol Biotechnol. 2004;14:1295-302.

74. Akino T, Kato C, Horikoshi K. The cloned $\beta$-mannanase gene from alkalophilic Bacillus sp. AM-001 produces two $\beta$-mannanases in Escherichia coli. Arch Microbiol. 1989;152:10-5.

75. Yang M, Zhang W, Ji S, Cao P, Chen Y, Zhao X. Generation of an artificial double promoter for protein expression in Bacillus subtilis through a promoter trap system. PLoS ONE. 2013;8(2):e56321.

76. Summpunn P, Chaijan S, Isarangkul D, Wiyakrutta S, Meevootisom V. Characterization, gene cloning, and heterologous expression of $\beta$-mannanase from a thermophilic Bacillus subtilis. J Microbiol. 2011;49(1):86-93.

77. Van Zyl PJ, Moodley V, Rose SH, Roth RL, van Zyl WH. Production of the Aspergillus aculeatus endo-1,4-beta-mannanase in A. niger. J Ind Microbiol Biotechnol. 2009;36(4):611-7.

78. Wang YP, Rao B, Zhang L, Ma L. High-level expression of two thermophilic B-mannanases in Yarrowia lipolytica. Protein Expr Purif. 2017;133:1-7.

79. Sak-Ubol S, Namvijitr P, Pechsrichuang P, Haltrich D, Nguyen TH, Mathiesen G, Eijsink VG, Yamabhai M. Secretory production of a betamannanase and a chitosanase using a Lactobacillus plantarum expression system. Microb Cell Fact. 2016;15:81.

80. Vu TT, Quyen DT, Dao TT, Nguyen ST. Cloning, high-level expression, purification, and properties of a novel endo-beta-1,4-mannanase from BacilIus subtilis G1 in Pichia pastoris. J Microbiol Biotechnol. 2012;22(3):331-8.
Ready to submit your research? Choose BMC and benefit from:

- fast, convenient online submission

- thorough peer review by experienced researchers in your field

- rapid publication on acceptance

- support for research data, including large and complex data types

- gold Open Access which fosters wider collaboration and increased citations

- maximum visibility for your research: over 100M website views per year

At BMC, research is always in progress.

Learn more biomedcentral.com/submissions 